National Library

of Canada

Acquisitions and

Bibliographic Services Branch

395 Wellington Sireet

OHawa. Ontario

KIAONA
Bibliothéque nationale

du Canada

Direction des acquisitions $e$

des services bibliographiques

395, ne Wellinglon

Ottawa (Onlario)

You the Hotsetelenemie

Authe Notic idterence

NOTICE

AVIS

The quality of this microform is heavily dependent upon the quality of the original thesis submitted for microfilming. Every effort has been made to ensure the highest quality of reproduction possible.

If pages are missing, contact the university which granted the degree.

Some pages may have indistinct print especially if the original pages were typed with a poor typewriter ribbon or if the university sent us an inferior photocopy.

Reproduction in full or in part of this microform is governed by the Canadian Copyright Act, R.S.C. 1970, C. C-30, and subsequent amendments.
La qualité de cette microforme dépend grandement de la qualité de la thèse soumise au microfilmage. Nous avons tout fait pour assurer une qualité supérieure de reproduction.

S'il manque des pages, veuillez communiquer avec l'université qui a conféré le grade.

La qualité d'impression de certaines pages peut laisser à désirer, surtout si les pages originales ont été dactylographiniées à l'aide d'un ruban usé ou si l'université nous a fait parvenir une photocopie de qualité inférieure.

La reproduction, même partielle, de cette microforme est soumise à la Loi canadienne sur le droit d'auteur, SRC 1970, c. C-30, et ses amendements subséquents. 


\title{
A Protein Tyrosine Kinase Associated with the ATP-dependent Inactivation of Adipose Diacylglycerol Acyltransferase ${ }^{l}$
}

\author{
by
}

Timothy E. Lau*

A thesis submitted to the School of Graduate Studies of the University of Ottawa in partial fulfiment of the requirements for the degree of Master of Science

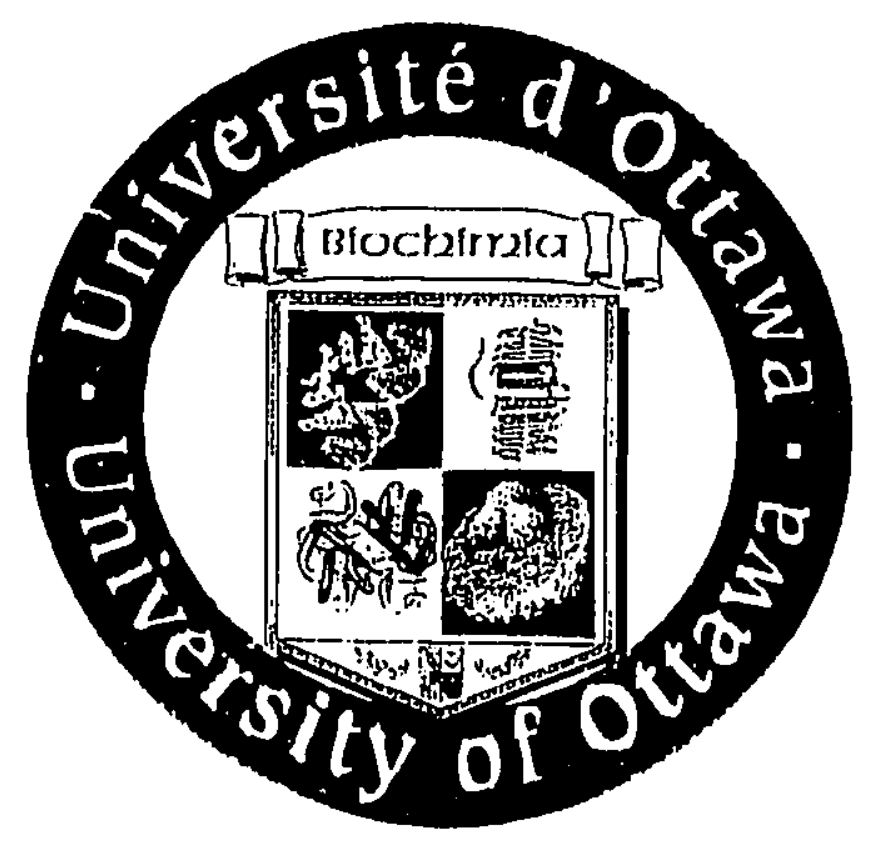

University of Ottawa, Depatment of Biochemistry, Faculty of Medicine Ottawa, Ontario, Canada, K1N 6 N5.

(C) Timothy E. Lau, Ottawa, Canada, 1995 
National Librany

of Canada

Acquisitions and Bibliographic Services Branch

395 Wellington Street Ottawa. Ontario KIA ON4
Bibliothèque nationale du Canada

Direction des acquisitions et des services bibliographiques

395, ne Wellington Ottawa (Ontario) K1AON4
THE AUTHOR HAS GRANTED AN IRREVOCABLE NON-EXCLUSIVE LICENCE ALLOWING THE NATIONAL LIBRARY OF CANADA TO REPRODUCE, LOAN, DISTRIBUTE OR SELL COPIES OF HIS/HER THESIS BY ANY MEANS AND IN ANY FORM OR FORMAT, MAKING THIS THESIS AVAILABLE TO INTERESTED PERSONS.
L'AUTEUR A ACCORDE UNE LICENCE IRREVOCABLE ET NON EXCLUSIVE PERMETTANT A LA BIBLIOTHEQUE NATIONALE DU CANADA DE REPRODUIRE, PRETER, DISTRIBUER OU VENDRE DES COPIES DE SA THESE DE QUELQUE MANIERE ET SOUS QUELQUE FORME QUE CE SOIT POUR METTRE DES EXEMPLAIRES DE CETTE THESE A LA DISPOSITION DES PERSONNE INTERESSEES.
THE AUTHOR RETAINS OWNERSHIP OF THE COPYRIGHT IN HIS/HER THESIS. NEITHER THE THESIS NOR SUBSTANTIAL EXTRACTS FROM IT MAY BE PRINTED OR OTHERWISE REPRODUCED WITHOUT HIS/HER PERMISSION.
L'AUTEUR CONSERVE LA PROPRIETE DU DROIT D'AUTEUR QUI PROTEGE

SA THESE. NI LA THESE NI DES EXTRAITS SUBSTANTIELS DE CELLECI NE DOIVENT ETRE IMPRIMES OU AUTREMENT REPRODUITS SANS SON AUTORISATION.

ISBN $\quad 0-612-04928-0$ 


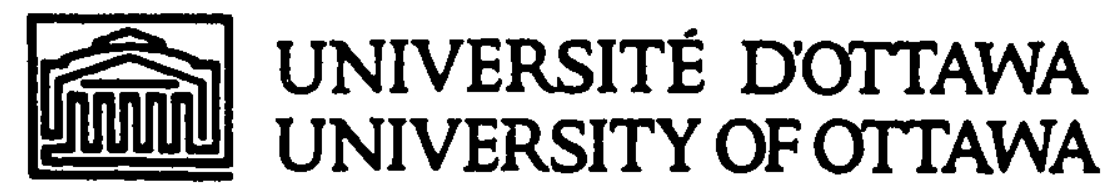




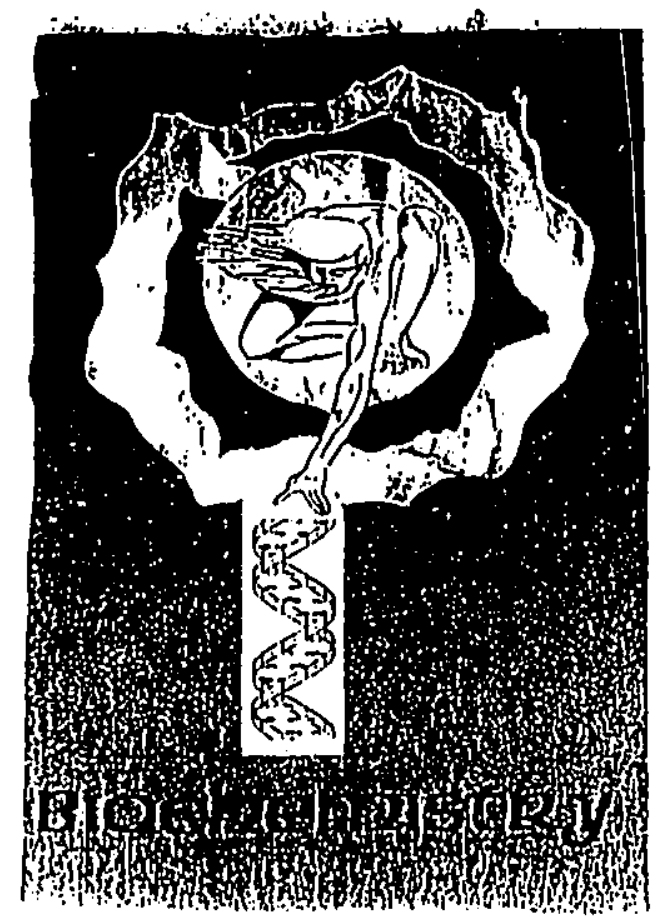

when r'oun consifier phusieal and chemical reactions,

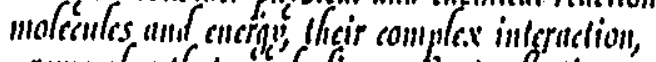
remenlier that ourt bodies are just colledions of atoms in mer'ics and tissues, in cross section.

But what alourt frec wifl which we exert cuch dau,

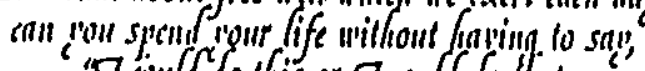

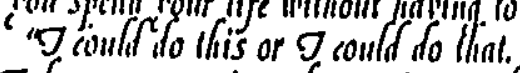

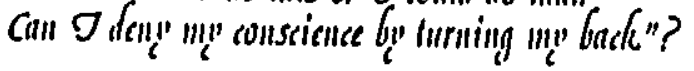

Alun! befiege our choices are muals, "11/en jossible options are visilin' laid,

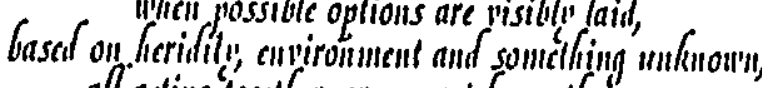

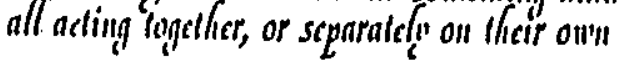

If that unfuson'n component were proven not to exist our immnorn decisions yould fie rediticed to a socictal anst. all of man's free choices woulf, in essentce, fecomic actions of molecules their interaction the sum 


\begin{abstract}
An enzyme activity that reversibly inactivates adipose glycerolphosphatc acyltransferase (GPAT) and diacylglycerol acyltransferase (DG $\wedge^{\prime} \mathrm{l}^{\prime}$ ), in, vitro, in the presence of ATP, has been partially purified from adipose tissue wilh an apparent molecular weight of $68 \mathrm{kDa}$. The activity responsible for inactivating DGAT is associaticd with a kinase activity as determined by phosphate incorporation into microsomes and a tyrosine containing peptide. Major substrates of this kinase are two microsomal polypeptides of 53 and $69 \mathrm{kDa}$. Both DGAT inactivation and kinase activities assayed from the purified sample and the cytosol, have been found to be insensitive to the Ser/Thr kinase inhibitor H-7 while being sensitive to the inhibitors genistein and tyrphostin 25 . A crude protein phosphatase preparation from the liver was capable of reversing the effects of both activities. The purified sample was also shown to inactivate GPAT in the presence of ATP. These results suggest that a protein tyrosine kinase, in concert with a protein tyrosine phosphatase, may regulate the activities of DGAT and GPAT by a phosphorylation-dephosphorylation mechanism.
\end{abstract}




\section{DEDICATION}

This thesis is dedicated to the ones I love, my parents who instilled in me the importance of striving for excellence and to Amy who was there to support me by her understanding, encouragment and patience but whose name says it all. I would also like to dedicate this thesis to my supervisor for giving me a project that worked out so well. I can appeciate how the best supervisors and teachers often never get the recognition they deserve. 


\section{ACKNOWLEDGEMENTS}

I would first like to thank my supervisor, Dr. Miguel Rodrigue\%, lor giving me the opportunity of working in his laboratory and for his excellem guidance, superior knowledge and clarity of thought. I am grateful that my medical career has taken this detour because I feel I have become a better and more chatritable person for having known him. My horizons have expanded and now my universe is not restricted to quarks, gluons, and electromagnetic fields but through logic and reasoning now includes the philosophy of free will, morality and spiritual reality. I am also grateful for a resource I feel I have exclusively amongst graduate students, the technicians in the student labs; P. Pilon, F. Hsich, C. C'lement, and P. Houlihan, for their time, guidance and use of ecuipment over the lass fow years. I am also grateful for the help with the HPLC analysis provided hy celine Clement. I would also like to thank Sylvic for helping me work wilh animals and preparing their tissues which I dreaded so much. I also thank (.. Dias for introducing me to research and the importance of coffec breaks in insuring a zest filled work-day, E. Lavictoire for her help with the application of lle: dilferem nutrition regimens, the preparation of the microsomes, and $D G{ }^{\prime} \mathrm{T}$ assilys during her honours thesis (Table 1), Dr. Himms-Hagen, Dr. Welsh, and Dr. Kattes for their assistance as members on my committec, S. Faucher for being such a pest for a while, and A. Fleming, and H. Amyot for their help in preparing various manuscripts and for being so generous and friendly. 


\section{TABLE OF CONTENTS}

\section{INTRODUCTION}

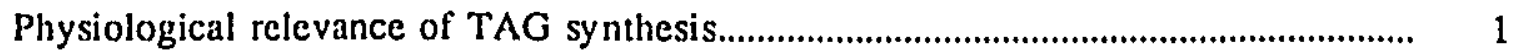

Liver vs. adipose tissue TAG synthesis..................................................................... 3

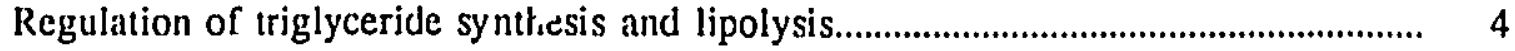

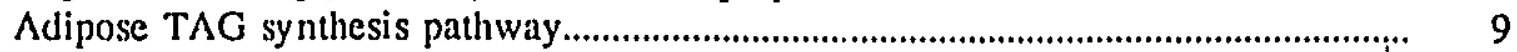

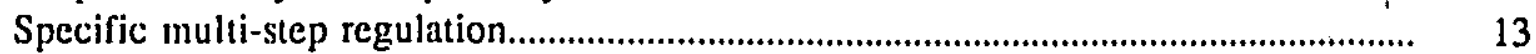

Involvement of protein kinases as avenues of regulation.......................................... 15

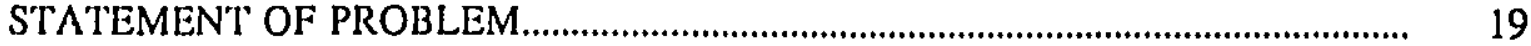

\section{MATERIALS AND METHODS}

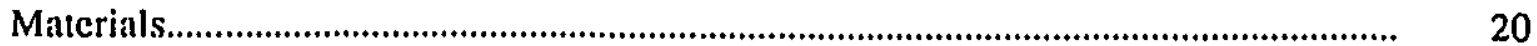

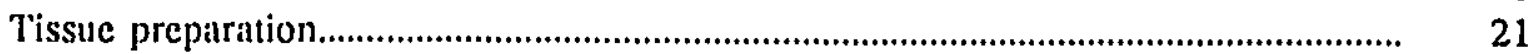

Purification of the activity responsible for DGAT inactivation................................... 21

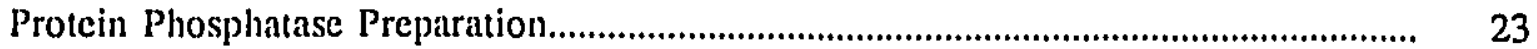

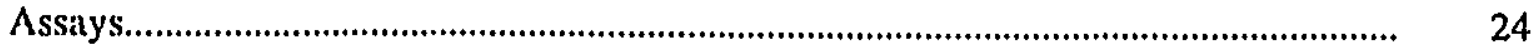

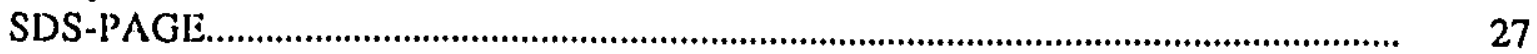

\section{RESULTS}

Localization of the activity responsible for DGAT inactivation.................................... 28

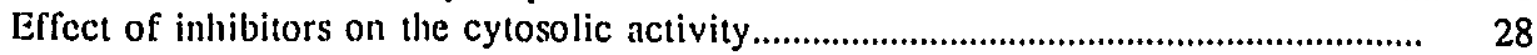

Effect of nutritional state on cytosolic activity......................................................... 31

Cytosolic activity from liver vs. adipose tissue........................................................ 33

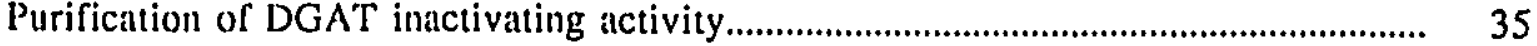

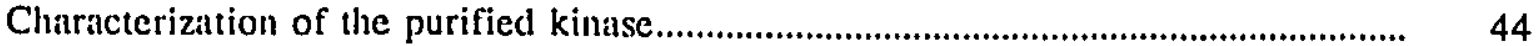

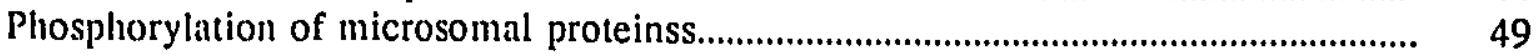

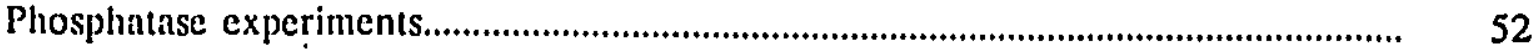

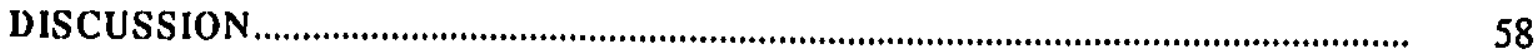

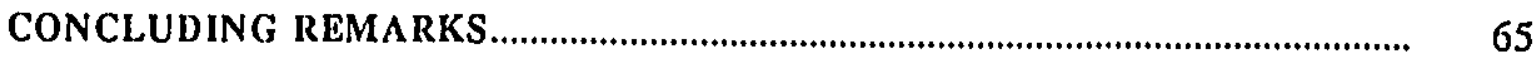

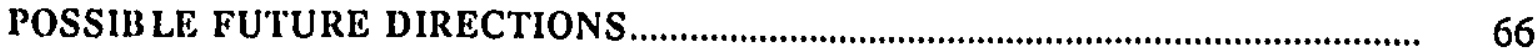

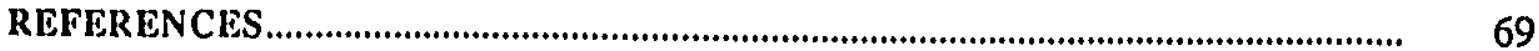

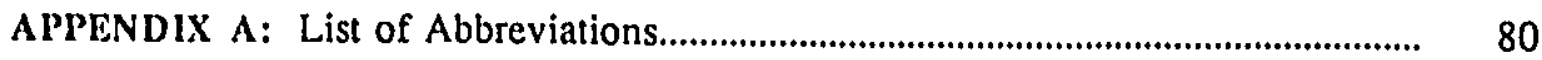

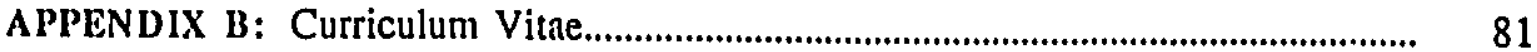




\section{LIST OF FIGURES}

Figure

1

2

3

4

5

6

7

8

9

10

11

12

13

14

15

16

17
Title

l'ange

Pathways of glycerolipid synthesis.

Triglyceride synthesis in adipose tissuc.

Localization of the activity responsible for DGAT inactivation....

Effect of kinase inhibitors on cytosolic activity

Flowchart of the purification sequence

Elution profile for the Blue Sepharose column

Elution profile for the S-sepharose column

Elution profile for the DEAE-sepharose column

Elution profile for the Sephacryl column.

HPLC Analysis of a Sephacryl pool

SDS PAGE of the partially purified kinase.

Effect of kinase inhibitors on the purified kinasc

Protein phosphorylation of microsomal proteins.

Protein phosphorylation by different cytosolic fractions.

Reversibility of DGAT inactivation and microsomal phosphorylation

Phosphatase treatment of kinase labelled microsomal proteins.....

Hypothetical regulation of triglyceride synthesis in adipose tissue

62 


\section{LIST OF TABLES}

Table

.Title

Page

I Different FED states and the corresponding changes in DGAT activity and in the ATP-dependent DGAT inactivation................................................ 32

II Cross inactivation of DGAT from adipose and liver tissue fractions............... 34

III Purification sequence of the kinase associated with DGAT inactivation......... $\quad 44$

IV Effect of cytosolic fraction on different substrates........................................ 46

$\mathrm{V} \quad$ Inhibition of DGAT reactivation with protein phosphatase............................. 53 


\section{1 \\ INTRODUCTION}

Physiological relevance of adipose TAG synthesis. Triacylglycerols are actively synthesized in the cells of vertebrates predominately in the liver and adipose tissue. In higher animals the highly specialized adipocyte is the primary repository of energy, stored as triacylglycerol in the intracellular lipid droplet. White adipose tissue has evolved, particularly in mammais for the storage of long chain latty acids in times of energy surplus and the mobilization of fatty acids out of the triacylglycerol stores in times of anticipated or actual energy demand. Whereas in a normal day up to $80 \%$ of the energy requirements of a man can be met by fatty acids (1), in times of energy surplus and the requirement for net fat deposition, rat adipocytes can increase their triacylglycerol content by an incredible $5 \%$ per hour (2). There is a continuous turnover of the stores, but net mobilization or deposition will depend on the balance of the relative activities of the hydrolytic and esterification processes. Although the enzymes involved in both the synthesis and lipolysis are known, the molecular process by which co-ordinated regulation is achieved remains a mystery. The elucidation of these processes may be important for understanding not only how organisms regulate their daily energy requirements and hence general metabolism, but also disorders of excessive lipid storage such as obesity or the severe depletion of energy reserves, such as occurs with the cachexia of chronic illness. Moreover abnormal lipid depositions 
have been identified in a number of pathophysiological conditions in which cells may assume adipocyte characteristics, including foam cells of athersclerotic plaques $(3,4)$ and certain rare conditions such as ichthyosis in which a variety of cells become lipid laden (5).

As mentioned above, the amount of FA released by adipose tissue into circulation is determined by the balance between TAG synthesis and hydrolysis. Recent reports suggests that plasma levels of free fatty acids are involved in the regulation of lipid and glucose oxidation and of glycogen synthesis in humans $[6,7]$. Impaired FA delivery to the adipose tissue, low levels of adipose TAG synthesis due, for instance to the abnormal regulation of the enzymes in the TAG synthetic pathway, may cause an imbalance of lipolysis and esterification preventing the uptake of fatty acids into adipose tissue. As a consequence, more fatty acids might either be released from adipose tissue or fail to be stored there, in either case reaching the liver and causing hepatic TAG synthesis to increase and VLDL secretion to rise. In vitro stimulation of VLDL synthesis and secretion in hepatocytes incubated with FA has been shown (8-10). Thus it has been suggested that hypertriglyceridemia (hyper TG) and hyperapobetalipoproteinemia (hyperapoB) might often be due to a reduced rate of adipose tissue TAG synthesis $(11-17)$. This may thereby result in an array of pathological conditions from 
obesity to athersclerosis. For instance it has been shown that in vitro incorporation of exogenous fatty acid into diacylglycerol and triacylglycerol proceeds at a slower rate in adipose tissue as well as in fibroblasts from hyperapoB patients in whom hyperTG is also frequent $(17,18)$. Moreover as will be discussed later high levels of plasma fatty acid could also explain some cases of diabetes (NIDDM) associated with obesity.

Liver vs. adipose TAG synthesis. Considering their different respective roles in metabolism, TAG synthesis in liver and white adipose tıssue must be regulated in a different manner since conditions of adipose lipolysis correspond to hepatic esterification, as exemplified in the fasting state when TAG synthesis and subsequent packaging into VLDL is elevated while in adipose lissue net TAG synthesis is reduced (19). In liver it has been proposed that control of glycerolipid synthesis is significantly influenced in a manner secondary to events regulating the alternative fate of fatty acids in that tissue, namely $\beta$-oxidation (20). This is most likely not the case in white adipose tissue since rates of fatty acid oxidation are extremely low relative to esterification (21) and therefore changes in oxidation would have neglible effects on esterification. Whereas most of the previous work on the regulation of TAG synthesis has been performed on the liver, we focused on adipose tissue where TAG synthesis is much higher and plays a central role in cell function. Since the regulation in both tissues is expected to be different, 


\section{4}

precaution is required when comparing results from both tissues. However, it would be interesting to perform comparative studies between both tissues.

Regulation of TAG synthesis and lipolysis. It is generally accepted that the coordinated hormonal regulation of both lipolysis and synthesis allows the adipocyte to respond rapidly and efficiently to the energy demands of the organism while reducing to a minimum the energy waste associated with the futile cycle of fatty acid esterification and hydrolysis. Although the molecular mechanisms of the hormonal regulation of lipolysis have been extensively studied and generally agreed upon, the molecular events involved in the hormonal regulation of triacylglycerol remains undetermined.

The rate of triacylglycerol mobilization of fatty acids from adipose tissue is dependent upon the interplay between a number of factors both in the short and long term which have been elucidated in the early eighties (22-24). The central feature of lipolysis is the hormone sensitive lipase (HSL) which catalyzes the hydrolysis of triacylglycerol to diacylglycerol and diacylglycerol to monoacylglycerol. The hydrolysis of the resulting monoacylglycerol is mainly catalyzed by a separate monoacylglycerol lipase. Hormone sensitive lipase is activated by protein kinase A (PKA) (25-29) and it is now established that this is due to the phosphorylation of the enzyme at a single serine residue (30). Dephosphorylation and deactivation 
of the lipase can be achieved by cellular protein phosphatases $1 A, 2 A$, and $2 C(24)$.

An assortment of lipolytic and antilipolytic agents acting through plasma membrane receptors (32) are able to influence the activity state of adenylate cyclase, through G-proteins, and thereby the level of CAMP and the activity of protein kinase A (PKA). The most frequently considered lipolytic hormones are adrenaline and noradrenaline (acting at $\beta$-adrenoreceptors), corticotropin, and glucagon all of whose receptors are coupled to the catalytic subunit of adenylate cyclase by its stimulatory G-protein (33). On the other hand, receptors for antilipolytic agents such as adenosine, PGE's, and nicotinate are coupled to adenylate cyclase by an inhibitory G-protein (33). The antilipolytic action of insulin, on the other hand, may in part be attributable to the decrease in CAMP levels [34] and PKA activity, although part of the hormone's effect is CAMP independent and is suggested to be due to the activation of phosphoprotein phosphatases (35).

A majority of the research focusing on the hormonal regulation of TAG synthesis was also performed from $1975-1985$, but progress was hampered by the fact that the corresponding enzymes are integral membrane proteins and remain to be purified. As will be discussed below the research was locused on the 


\section{6}

involvement of PKA and little attention was given to other possible phosphorylation systems. The existence of long term (e.g., starvation) and short term (i.e., hormonal) regulation of adipose triacylglycerol synthesis is well documented although the particulars are unknown. Starvation and streptozotocin diabetes result in decreased synthetic enzyme activities (2). Traditionally, changes in circulating levels of insulin in response to variations in blood glucose concentration, have been considered the physiological signal determining the conversion between glucose and fatty acid metabolism. In addition to increases in LPL activity/secretion and substrate transport in response to glucose and insulin, adipose tissue responds to that switch by modifying the rate of fatty acid release(2). There appears to be evidence that adipose tissue can overide the glucose-insulin signal system and impose fatty acid utilization even in the face of high levels of circulating glucose and insulin (7), as it seems to be the case of obesity-related insulin resistance which, in some cases, may be secondary to high levels of circulating fatty acids.

The rate of esterification of long chain fatty acids into neutral glycerides is dependent on the availibility of the respective substrates and the in situ activity of the participating enzymes(36). Regulation of esterification could either occur via changes in substrate availability (or delivery) and/or enzyme modification. However some have suggested that TAG synthesis is regulated exclusively by 


\section{7}

substrate availability but this is unlikely for the following reasons.

1) Regulation by fatty acid availability alone should result in changes in levels of intermediates in response to changes in the delivery of substrates. Some of these intermediates are toxic to the cell and there appears to be no significant changes in their levels $(36,37)$.

2) Moreover, increased levels of lipolytic hormones and/or diminished levels of insulin cause triacylglycerol mobilization, and in vitro a certain proportion of mobilized fatty acid is recycled into triacylglycerol when adipocytes are incubated in closed systems (38-40). Although in vivo blood flow may diminish this to an extent, there is nevertheless evidence for triacylglycerol/fatty acid substrate cycling (41). It has been suggested previously that rapid down regulation of the TAG synthetic enzyme activities under lipolytic conditions is important to restrain wasteful recycling of mobilized fatty acids back into triacylglycerol stores (2).

3) Experiments have shown the modification of enzyme activities and the corresponding changes in net TAG synthesis during both fed/fasting states and hormonal treatment (2). This implies a direct regulation of the enzymes as opposed to regulation of T.AG synthesis by the availability of respective substrates.

It is therefore believed that regulation occurs by substrate availability in addition to changes in the activities of the corresponding enzymes. There is no clear rate limiting step (except possibly at the DGAT step (36)) in the synthesis pathway and the enzymes appear to be functioning well below saturating 
conditions (37). Since hormonal regulation at a single step would also result in an accumulation of intermediates which is not observed $(36,37)$, it is logical to assume that regulation occurs at more than one step by the same hormonal signal. This may be accomplished through a phosphorylation/dephosphorylation of multiple enzymes in the synthetic pathway by a kinase/phosphatase system.

Other mechanisms of TAG synthesis regulation may involve control of the delivery of fatty acid and product inhibition. The mechanism of regulation of both transport of extracellular fatty acid to TAG synthesis loci and the TAG synthetic enzymes are not yet clear. Whatever the transport mechanism, there appears to be in the cell a free fatty acid pool exchangeable with the extracellular fatty acid pool. The intracellular pool itself may bind reversibly to cellular components, both membranes and proteins (42). This pool must somehow be compartmentalized, since exogenous radiolabelled fatty acid can be readily esterified before the complete mixture with the intracellular free fatty acids is attained (43). The distribution of free fatty acids between the different compartments may play an important role in the regulation of fatty acid release and uptake. For instance under lipolytic conditions and in the absence of albumin in the medium, the accumulation of free fatty acid in the adipocytes inhibits lipolysis $(42,45)$. It has been shown that incubation of adipocyte microsomes with micromolar concentrations of oleic acid results in the inhibition of fatty acid esterification to 
either glycerol phosphate or diglycerides (46). Another possible mechanism which has been suggested by Abumrad et al. is the catecholamine-mediated stimulation of fatty acid transport out of the adipocyte (47). Thus the results suggest that free fatty acid and its delivery may play a role in the modulation of TAG synthesis enzymes.

Additionally fatty acid binding proteins (FABP's) have been proposed to be involved in the transport of free fatty acid across the plasma membrane and the cytosol to the ER for esterification, and to the mitochondria and peroxisomes for oxidation $(48,49)$. Fatty acids bound to these FABPs may account for a good part of the active intracellular pool of free fatty acids. FABPs as well as other uncharacterized cytosolic proteins, have been shown to stimulate the TAG synthetic enzymes (50-55), although it is not clear whether they cause their effect by improving substrate delivery or by interacting with the synthetic enzymes and modifying their activities. FABP may also modulate lipid synthesis by preventing excessive accumulation of fatty acid in the ER membrane.

Adipose TAG synthesis pathway. Adipose tissue glycerolipid synthesis is primarily devoted to the synthesis of TAGs with only a small fraction of the pathway flux arising in phospholipid products (2)(refer to the pathways of glycerolipid synthesis shown in Figure 1). The intracellular lipid droplet where 


\section{0}

TAGs are stored has at its periphery a complex network of filaments $(56,57)$ as well as endoplasmic reticulum cisternae and tubules $(58,59)$ which may extend into the core of the lipid droplet forming aqueous channels (59). In metabolically active adipocytes the luminal leaflet of the channels contain fatty acid products of triacylglycerol hydrolysis which are visualized under appropriate preparatory procedures as lamellar whorls (5Q), or lipid domains within the membrane leaflet (60). TAG formation in adipose tissue takes place on the ER membranes primarily through the glycerol phosphate pathway supplemented by the dihydroxyacetone pathway $(2,61)$. The sequential enzyme-facilitated esterification of long chain fatty acids in the biosynthesis of triacylglycerols in adipose tissue is depicted in Figure 2. The effect of a number of hormones on various TAG synthetic enzymes have been studied including glucocorticoids, catecholamines, glucagon, insulin, and growth hormone. A recent study with obese premenopausal women suggests that triglyceride synthesis is shut down in adipose tissue following growth hormone administration, an effect that is not secondary to its affects on lipolysis [62]. Assuming there is hormone mediated multi-step regulation of the pathway by enzyme modifications, then at which points in the synthetic pathway will regulation occur? 


\section{Figure 1. Pathways of Glycerolipid Synthesis}

Dihyciroxyacetone phosphate

(2)

Acyldihydroxyacetone plospliate

\section{More enzymes}

(l) phospholipase a activitic:s

(2) dihydronyacerone phosphinute

"scyllinusferuse

(.3) acyldihydroxyocetome phosphote rediciose' (4) phosphlowiclute

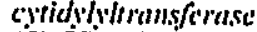
(5) CDP.dincylg/sctor). inositol 3 .

phosphatidyliransfercase (6) slycerol phosphate phosphaticlyltromsfertuse (7) phosphomidyl transfer from CDP-diculylglecerol 10 phospharidilglycerol (8) choline phesphlowransferases (9) cthonolamine phesphotromsforase'

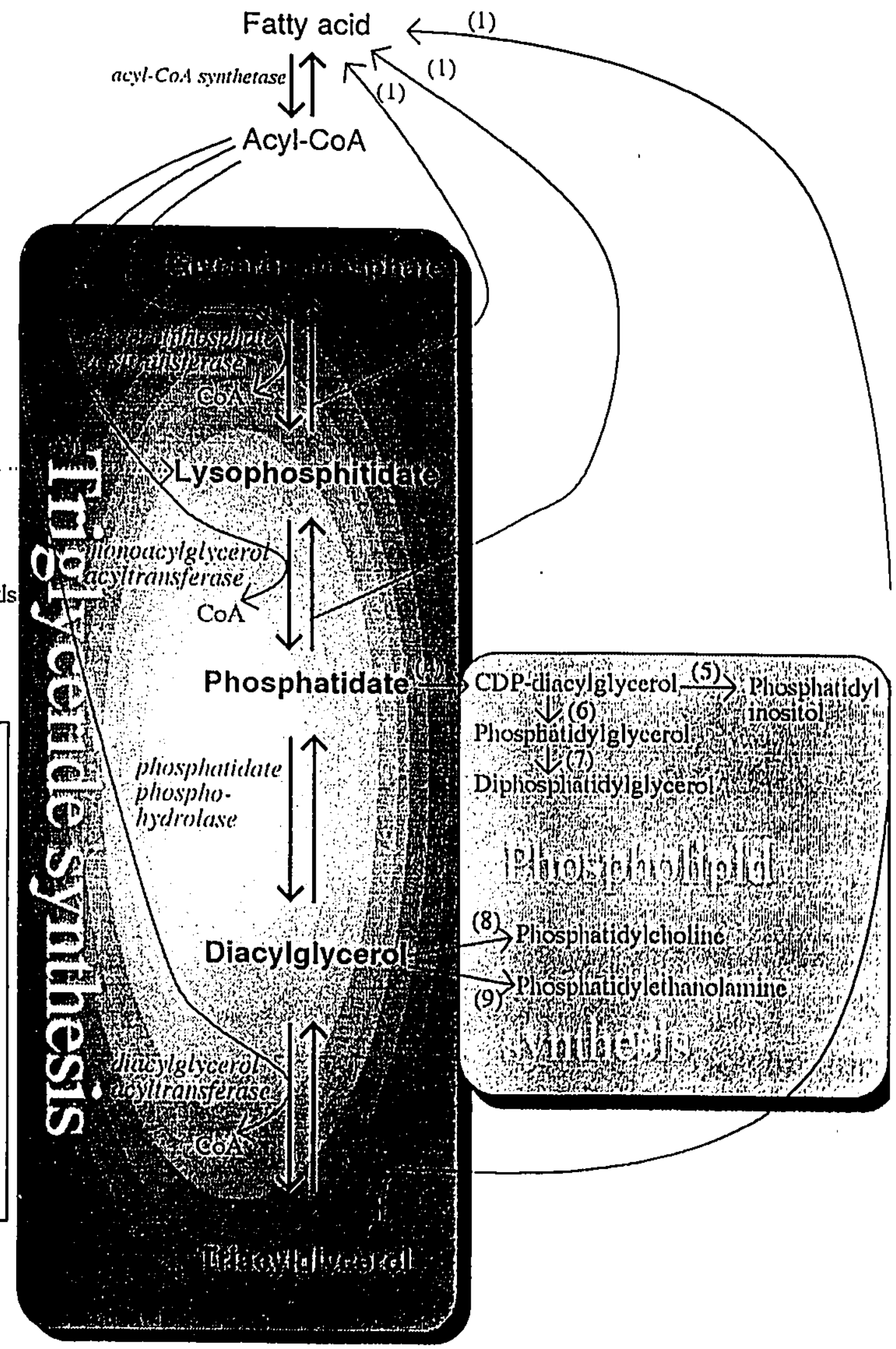


Figure 2.

Glucose
Triglyceride Synthesis in Adipose Tissue

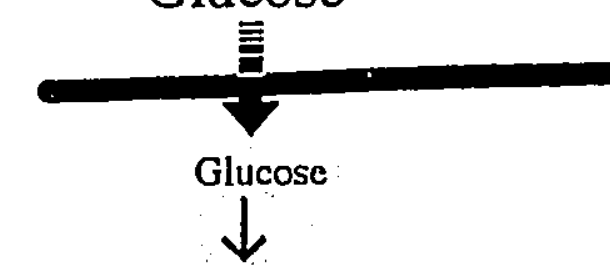

CYTOPLASM

G-3-P

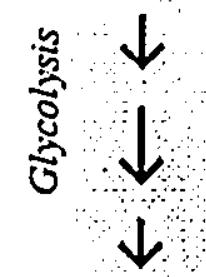

pyruvate

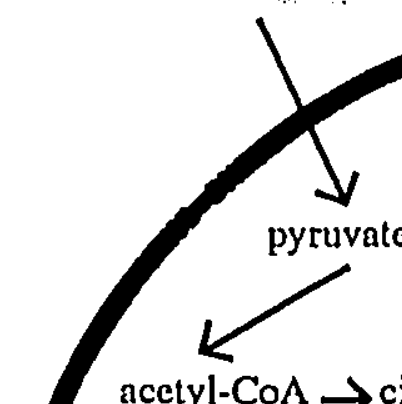

acetyl-CoA $\rightarrow$ citrate $\rightarrow$ acetyl-CoA $\rightarrow$ fatty acid

\section{MITO}

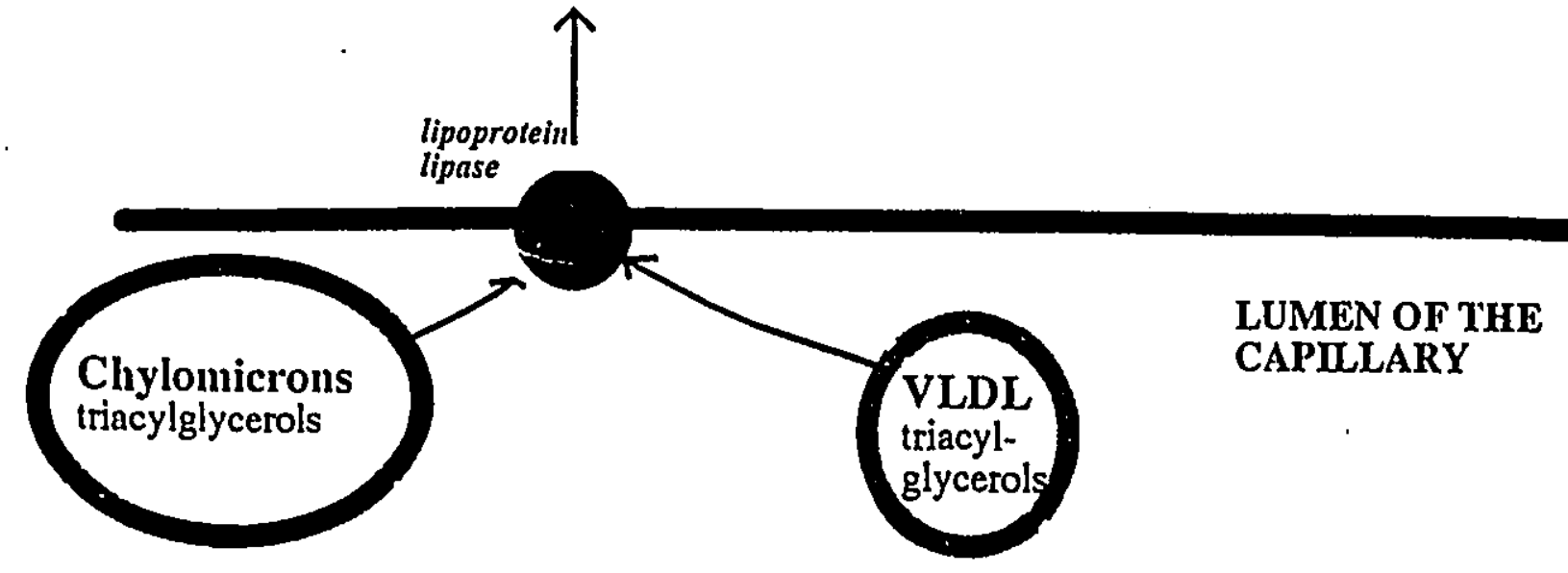

E. R.

glycerolphosphate

acjliransferase

Lysophosphatidic acid

mononcylglycerol

acjltiransferase

Phospliatidic acid
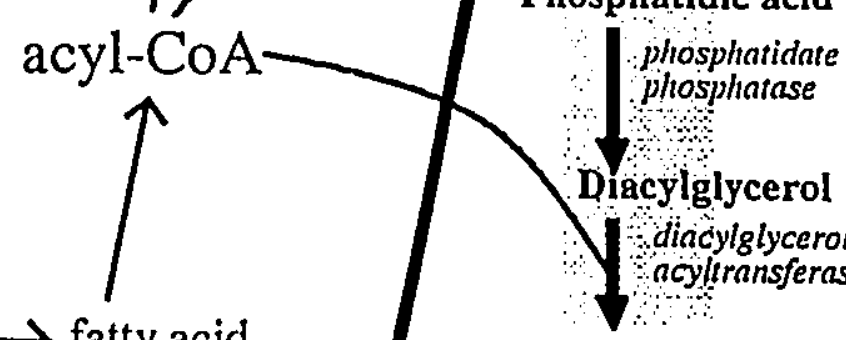

phosphatase

Diacylglycerol

udicicylglycerol

acyltransferase

triacylglycerol

LUMEN OF THE

CAPILLARY 
Specific multi-step regulation. Logically when considering the pathway and the intermediates, regulation at the level of glycerophosphate acyltransferase (GPAT) is certainly logical since this step results in committed TAG or PL synthesis. Catecholamines have been previously reported to decrease the activity of glycerolphospate acyltransferase (GPAT) $(63,64)$. Stimulation of GPAT activity measured in vitro was reported in adipocytes preincubated with insulin (65) and insulin both blocks the effects of catecholamines (64) and reverse the induced decreases in the activity of GPAT (66). The regulation of MGAT to make it rate limiting would cause the accumulation of LPA which is toxic to the cell since it is a strong detergent. Furthermore, in vitro studies suggest that it has the highest specific activity; therefore not an effective point of regulation (67). Regulation at the level of phosphatidate phosphatase as suggested for the liver by Brindley (68) could be relevant since PA is the branch point for the formation of non-polar PLs and triacylglycerols. Moreover catecholamines have also been previously reported to decrease the activity of phosphatidic acid phosphatase (PAP) (69). Insulin also blocks the effects of the catecholamines on PAP and rapidly reverse the effects of catecholamines (70). It has been suggested that hormonal regulation is achieved at the level of translocation of the enzyme between the cytosol and ER membranes (67) but this has been the subject of debate because there appears to be little correlation between net TAG synthesis and translocation $(36,37)$. Moreover since adipose cells do not significantly synthesize these PLs, 


\section{4}

translocation of the enzyme to the cytosol during hormonal down regulation would result in the accumulation of phosphatidic acid which would be unfavourable. Additionally it has been difficult to detect consistent alterations in the steady state of PA levels $(36,37)$.

Regulation at the level of DGAT may be important because it is the branch point for the formation of polar PLs and triacylglycerols (see Figure 1). In view of the different function of PLs and triacylglycerols, differential regulation at this branchpoint in all cell types is plausible, as it appears to be the case in hepatocytes $(71,72)$. There is evidence that alterations in DGAT activity affects both PL and TAG synthesis $(73,74)$. For instance a recent study demonstrates that inactivation of DGAT results in an increase in DAG incorporation into PL's (75) while other studies demonstrate that the availability of cellular diacylglycerol modulates TAG and PL synthesis $(73,76-77)$. Of all the steps in the TAG synthesis pathway, recent studies with permeabilized rat hepatocytes suggest that only DGAT has been found to be rate limiting (36). In adipose tissue, accumulation of diacylglycerol (DAG), during the attenuation of DGAT activity, would not pose a significant threat to membrane stability and function, and could therefore be an important rate determining step in the regulation of synthesis. In the liver, adipocytes, soybean, and developing seeds, there is evidence that DGAT plays an important role in the regulation of TAG synthesis $(36,37,67,76,78,79)$. 


\section{5}

Catecholamines have been previously reported to decrease the aclivity of DGAT (64) however a more recent report suggests that norepinephrine does not directly regulate triacylglycerol synthesis in adipocytes (47) but rather it is the liberation of fatty acids through lipolysis mediated by HSL which inactivates the enzymes. Glucagon has also been reported to decrease the activity of DGAT $(71,81)$ without affecting $\mathrm{PL}$ synthesis (71) although this is less important in human adipose tissue since there does not appear to be expression of glucagon receptors.

It is conceivable that in white adipose tissue DGAT, in addition to other TAG synthetic enzymes, demonstrates complex regulatory properties both in the short and long term. It is probably too simplistic to assign a dominant role to any regulatory enzyme in the overall control of glycerolipid synthesis. Rather it is better to think in terms of the multistep close-knit interplay between several key enzymes possibly mediated by kinases and phosphatases.

Involvement of protein kinases in regulation. Several in vitro experiments suggest that triacylglycerol synthetic enzymes, including GPAT, PAP and DGAT from various tissues, may be regulated by a phosphorylation-dephosphorylation mechanism. There are however, different kinases which have been implicated and conflicting reports on their effects on the enzymes has been reported $(63,66,72,82$. 86). It has been suggested previously that GPAT from cardiocytes (63) and 


\section{6}

adipocytes (82) are regulated by protein kinase $A$ through the actions of the $\beta$ adrenergic receptor. However other laboratories have been unable to observe any GPAT inactivation upon incubation of rat adipocyte microsomes with PKA and its substrates $(66,87)$. PAP from rat liver was also suggested to be regulated by a phosphorylation-dephosphorylation mechanism $(83,85)$ although this has yet to be confirmed.

Regulation of DGAT activity by reversible phosphorylation-dephosphorylation mechanism associated with signal transduction in exocrine cells was suggested by Soling et al. (84) although phosphorylation was reported to increase the activity of DGAT and the link of TAG synthesis to signal transduction at the plasma membrane is unclear. Although DGAT phosphorylation may be important in signal transduction, considering the differences in function of adipocytes and purely exocrine cells Soling's hyporthesis is probably irrelevant to studies of adipocyte TAG synthesis. Another recent report with $3 T 3$ adipocytes suggests that there appears to be the ATP-dependent formation of lipid protein complexes which stimulates DGAT activity (88) but the exact mechanism and physiological relavence with respect to regulation is obscure. Furthermore we have never detected an increase in DGAT activity following incubation of adipose tissue cytosol with microsomes and ATP. Modulation of DGAT activity in the liver by a phosphorylation-dephosphorylation mechanism was suggested previously by 


\section{7}

Haagsman and coworkers (72). Rat liver microsomes were shown to be inactivated in vitro by incubation with $\mathrm{ATP} / \mathrm{Mg}^{2+}$ and the liver cytosolic fraction but not with PKA and its substrates. The authors reported reactivation of DGAT activity from ATP treated microsomes upon incubation with liver cytosol. They also observed a decrease in DGAT activity of tissue homogenized in the presence of $40 \mathrm{mM} \mathrm{NaF}$. By contrast, we were unable to detect either of these Intter effecls in adipose tissue (89). We did find a consistent stimulation of both DGAT and GPAT activities by the cytosolic fraction. Similar stimulation has been reported previously in different laboratories although the mechanism of stimulation has nol yet been demonstrated $(87,89)$.

Previous studies from our laboratory indicate the presence in adipose tissue of an ATP-dependent activity that in vitro reduces both GPAT and DGAT activities by $30-40 \%(87,89)$. As was reported, the activity responsible for GPAT and DGAT is associated with the cytosolic fraction, is heat sensitive, requires $\mathrm{Mg}^{21}$, and an intact cleavable $\beta$ - $\gamma$-phosphodiester bond on the ATP. DGAT and GPAT activites from ATP treated microsomes can be restored to control levels by incubation with a crude preparation of liver protein phosphatase. New addition of ATP and cytosol results in reinactivation close to the level for ATP-treated microsomes (89). These results support the hypothesis of a soluble protein kinase involved in the regulation of adipose DGAT and GPAT. We also determined that DGAT inactivation was not 


\section{8}

affected by the inhibitors of PKC and or PKA such as $\mathrm{H7}$ analogue, staurosporine, amiloride, or PKA inhibitor. Furthermore since the stimulation of DGAT was not observed by the addition of $\mathrm{Ca}^{2+}$, CAMP, or the cAMP analogue chlorophenylthioCAMP, and because neither PKC from rat brain nor the catalytic subunit of PKA from bovine heart could replace the cytosolic activity, the postulated DGAT kinase is neither PKC nor PKA. 


\section{STATEMENT OF THE PROBLEM}

As was discussed in the introduction, our lab has recently described the presence of an enzyme activity in adipose tissue which in the presence of ATP reversibly inactivates GPAT (87) and DGAT (89). Our hypothesis was that the ATP-dependent inactivation of both acyltransferases is associated with a protein tyrosine kinase activity. To prove this hypothesis, experiments were designed in order to 1) purify from adipose tissue cytosol, the enzyme activity associated with inactivating DGAT, 2) determine if there is a kinase activity associated with the DGAT inactivation throughout the purification steps, 3) if a kinase is co-purified determine its substrate specificity (ie. ser/thre, dual, tyr), 4) determine the sensitivity pattern of both activities to inhibitors, 5) examine if the purified activily can also act on GPAT, 6) examine if a crude phosphatase preparation could reverse effects of DGAT inactivation and microsomal phosphorylation, and 7) identify polypeptide substrates of the purified kinase which may be components of adipose DGAT and GPAT. 


\section{0}

\section{MATERIALS AND METHODS}

Materials. Oleic acid, oleoyl-CoA, diolein (1,2-dioleoyl-sn-glycerol), L-glycerol 3phosphate, ATP, coenzyme A (CoA), DL-dithiothreitol (DTT), ethylenediaminetetraacetate (EDTA), bovine serum albumin (BSA) (essentially fatty acid free), 4',5,7-trihydroxyisoflavone (genistein), 1-(5-isoquinolinylsulfonyl)-2methyl-piperazine (H7), 2-aminopurine, staurosporine, [3,4,5trihydroxybenzylidene]-malononitrile (tyrphostin 25), tyrosine kinase substrate peptide (Arg-Arg-Leu-lle-Glu-Tyr-Ala-Ala-Arg-Gly), Reactive Blue 2-Sepharose, SSepharose, Sephacryl S-200, DEAE sepharose CL-6B, polyethylene glycol compound (MW 15,000-20,000), sodium dodecyl sulfate (SDS), acrylamide (TEMED, bisacrylamide), Brilliant Blue G colloidal, Fuji NIF-RX film, and molecular weight standards were obtained from the Sigma Chemical Co. (St. Louis, MO). Filters $(0.22 \mu \mathrm{m}$ pore size) were obtained from Millipore (Bedford, MA). Whatman P-81 paper was obtained from Canadawide Scientific (Ottawa, Ontario, Canada). $\left[9.10-{ }^{3} \mathrm{H}\right.$ Oleic acid $(7.4 \mathrm{Ci} / \mathrm{mmol})$ and L-[2- $\left.{ }^{3} \mathrm{H}\right]$ Glycerol-3-phosphate $(10.6 \mathrm{Ci} /$ mmole, $1 \mathrm{Ci}=37 \mathrm{GBq}$ ) were obtained from Du Pont Canada Inc. (Mississauga, Ontario, Canada). $\left[9,10-{ }^{3} \mathrm{H}\right]$ Oleoyl-CoA $(100 \mathrm{Ci} / \mathrm{mol})$ was prepared from the radioactive fatty acid following the method of Bishop and Hajra [90] as previously described [91]. ${ }^{32} \mathrm{P}-\gamma$-ATP (3 Ci/mmol) was obtained from Amersham (Oakland, Ontario, Canada). 


\section{1}

Tissue preparation. Epididymal adipose tissue microsomes from male Sprague Dawley rats (Charles River Canada Inc., St. Constant, Quebec, Canada) fed at libitum (except Table 1) were prepared by diffential centrifugation of the homogenized tissue as previously described [92,93]. After excision of blood vessels and debris, epididymal adipose tissue was homogenized in three volumes of a $10 \mathrm{mM}$ Tris $-\mathrm{HCl}(\mathrm{pH} 7.5)$ buffer containing $0.25 \mathrm{M}$ sucrose, and $1 \mathrm{mM} \mathrm{DTr}$ (buffer A). The homogenate was centrifuged at $600 \times \mathrm{g}$ and the fat cake and pellet were discarded while the supernatant was filtered through glass wool. The filtrate was centrifuged at $16000 \mathrm{xg}$. The supernatant (post-mitochondrial supernatant) was resolved into cytosol and microsomes by centrifugation at $100000 \mathrm{xg}$ for $1 \mathrm{~h}$. The microsomes were washed once, resuspended in buffer $A$ containing $1 \mathrm{mM}$ EDTA, to a final concentration of $1-2 \mathrm{mg}$ protein $/ \mathrm{mL}$ and kept in aliquots at $-60^{\circ} \mathrm{C}$. When indicated, to remove any endogenous kinase, the microsomes were further washed with a buffer containing $200 \mathrm{mM}$ Tris- $\mathrm{HCl}(\mathrm{pH} 9.0), 1 \mathrm{M} \mathrm{NaCl}, 1 \mathrm{mM}$ EDTA, $0.25 \mathrm{M}$ sucrose and $1 \mathrm{mM}$ DTT. Amounts of microsomes used in the experiments are indicated throughout this thesis as the mass of microsomal protein. Concentration of samples when desired, was perlormed by dialysis against solid polyethylene glycol (PEG).

Purification of the activity responsible for DGAT inactivation. The activily responsible for DGAT inactivation was purified by fractionation of $50 \mathrm{~mL}(150 \mathrm{mg}$ 


\section{2}

protein) of the $100,000 \times \mathrm{g}$ supernatant from homogenized adipose tissue, with fractions of the purification sequence tested for DGAT inactivation on washed microsomes $(8 \mu \mathrm{g})$. The cytosol was first mixed with solid ammonium sulfate to a concentration of $55 \%$ ammonium sulfate saturation and kept stirrred at $4^{\circ} \mathrm{C}$ for 1 hour. After centrifugation the pellet $(38 \mathrm{mg}$ ) was resuspended in TED buffer (50 $\mathrm{mM}$ Tris- $\mathrm{HCl}$ ( $\mathrm{pH} 7.5$ ), $1 \mathrm{mM}$ EDTA and $2 \mathrm{mM} \mathrm{DTT}$ ) dialyzed against TED and applied to a $20 \mathrm{~mL}$ Blue-Sepharose column followed by elutions with TED buffer containing $0,0.3$ and $1 \mathrm{M} \mathrm{NaCl}$. The protein peak which elutes at $0.3 \mathrm{M} \mathrm{NaCl}(9.4$ $\mathrm{mg}$ ) was dialyzed against TED buffer, applied to a $20 \mathrm{~mL}$ S-Sepharose column and eluted with $0.5 \mathrm{M} \mathrm{NaCl}$ in TED buffer. The pool containing the activity $<0.57$ $\mathrm{mg}$ ) was dialyzed, applied to a $7 \mathrm{~mL}$ DEAE Sepharose column and eluted with 1 $\mathrm{M} \mathrm{NaCl}$ in TED buffer. Fractions containing the activity $(0.29 \mathrm{mg})$ were pooled, concentrated with PEG and applied to a $45 \mathrm{~cm}$ Sephacryl S-200 column equilibrated with TED buffer. The final pool $(0.14 \mathrm{mg})$ of the fractions containing the activity was made $20 \%(\mathrm{v}: \mathrm{v})$ in glycerol and stored at $-20^{\circ} \mathrm{C}$.

High performance liquid chromatography (HPLC) analysis was performed with a Bio-Gel TSK Phenyl 5-PW hydrophobic Bio RAD column. The HPLC pump was a Beckman Model $110 \mathrm{~A}$ attached to a Beckman 340 flow regulator. Visualization of the protein peaks was achieved with an Hitachi Model 110-40 spectrophotometer. A cytosolic fraction $(50 \mu \mathrm{g})$ from a purification sequence 


\section{3}

including an ammonium sulfate precipitation, blue sepharose, phosphocellulose, DEAE-sepharose, and sephacryl chromatographies, followed by dialysis of the final pool with polyetheylene glycol to a concentration of $100 \mu \mathrm{g} / \mathrm{mL}$ was applied to the HPLC column followed by a $1 \mathrm{M}$ to $10 \mathrm{mM}$ ammonium phosphate gradient to achieve maximal resolution of the peaks. Flow rate was set at $1 \mathrm{~mL} / \mathrm{min}$ and analysis and trials were performed by Celine Clement.

Protein phosphatase was partially purified from rat liver up to the ethanol precipitation step of the method of Brant et al. (94) as previously described (89). The liver tissue was homogenized in three volumes of a $10 \mathrm{mM}$ Tris bulfer $(\mathrm{pH}+\mathrm{H} .5)$ containing $0.25 \mathrm{M}$ sucrose, $1 \mathrm{mM}$ DTT and $1 \mathrm{mM}$ EDTA (buffer $B$ ). $1 \mathrm{gm}$ Norit $\wedge$ charcoal/L homogenate and acetic acid was added to achieve a pH of 5.8 for the acid precipitation. The mixture was centrifuged at $10000 \mathrm{xg}$ for $20 \mathrm{~min}$. and the supernatant was adjusted to a $\mathrm{pH}$ of 7.2 with Tris base. Ammonium sulfate was added to a concentration of $70 \%$, for the precipitation of protein. The $\mathrm{pH}$ was again readjusted to 7.2 and the mixture was centrifuged at $10000 \times \mathrm{g}$ for $20 \mathrm{~min}$. The pellet was redisolved in a minimum volume of a $20 \mathrm{mM}$ Tris buffer containing $1 \mathrm{mM} \mathrm{MgCl} 2$. The solution was then poured into five volumes of $95 \%$ ethanol and centrifuged at $5000 \times \mathrm{g}$ for $5 \mathrm{~min}$. The pellet was extracted by homogenization with $0.5 \mathrm{~mL}$ buffer $B$ per gram of liver. The suspension was centrifuged at $16000 \mathrm{xg}$ for $15 \mathrm{~min}$ and the pellet was extracted again. The supernatants were combined 


\section{4}

and dialyzed against buffer B. A final concentration of $5.0 \mathrm{mg}$ protein $/ \mathrm{mL}$ was achieved by concentration with solid polyethylene glycol and an equal volume of glycerol was added to the extract and kept at $-90^{\circ} \mathrm{C}$.

Assays. GPAT was assayed as previously described (87). The assay was performed at $37^{\circ} \mathrm{C}$, normally for $4 \mathrm{~min}$, in a final volume of $0.5 \mathrm{~mL}$ containing 0.1 $\mathrm{M}$ Tris- $\mathrm{HCl}(\mathrm{pH} 7.5), 2 \mathrm{mM}$ DTT, $10 \mathrm{mM} \mathrm{MgCl}, 25 \mu \mathrm{M} \mathrm{BSA}, 100 \mu \mathrm{M}$ oleoyl-CoA, $1 \mathrm{mM}\left[{ }^{3} \mathrm{H}\right] \mathrm{glycerol}-3$-phosphate $(1.2 \mathrm{Ci} / \mathrm{mol})$, and microsomes $(5-10 \mu \mathrm{g})$. Incubation for 4 minutes following the addition of $\left[{ }^{3} \mathrm{H}\right]$ glycerol-3-phosphate and oleoyl-CoA was terminated by the addition of $1 \mathrm{~mL}$ of butanol saturated with water. The aqueous and organic phases were separated by centrifugation in a clinical centrifuge. The organic phase was washed three times with $1.5 \mathrm{~mL}$ of water saturated with butanol. A $0.5 \mathrm{~mL}$ aliquot of the organic phase was counted in 7 $\mathrm{mL}$ of Universol.

DGAT was assayed as we previously described [89]. DGAT was assayed by incubating the microsomes $\left(10-20 \mu \mathrm{g}\right.$ protein) for $6-8 \mathrm{~min}$ at $37^{\circ} \mathrm{C}$ with exogenous([95](Rodriguez, Dias, Charoui, and Lau) $20 \mu \mathrm{M} 3 \mathrm{H}$-oleoyl-CoA $(7.5$ $\mathrm{Ci} / \mathrm{mol}$ ) and $150 \mu \mathrm{M}$ 1,2-dioleoyl-sn-glycerol (delivered in $5 \mathrm{~mL}$ acetone) in $0.5 \mathrm{~mL}$ of $0.1 \mathrm{M}$ Tris- $\mathrm{HCl}(\mathrm{pH} 7.5)$, containing $1 \mathrm{mM} \mathrm{DTT}, 10 \mathrm{mM} \mathrm{MgCl}_{2}$ and $5 \mathrm{uM} \mathrm{BSA}$ (TMB buffer). The reaction was stopped by the addition of $1.5 \mathrm{~mL}$ of 
isopropanol/hexane $(1: 1, \mathrm{vol} / \mathrm{vol})$. The organic phase was washed three times with $0.75 \mathrm{~mL}$ of isopropanol/hexane $(4: 1, \mathrm{vol} / \mathrm{vol})$ and $0.75 \mathrm{~mL}$ of $0.05 \% \mathrm{KOH}$. A 0.75 $\mathrm{mL}$ aliquot from the organic (hexane) phase was counted in $7.5 \mathrm{~mL}$ of Universol scintillation cocktail in an LKB Wallac 1214 beta counter. ATP-dependent GPAT and DGAT inactivation were determined by performing the corresponding assays with the cytosolic fraction, in the presence and absence of $0.5 \mathrm{mM}$ ATP.

DGAT activity was assayed in the liver without resolution of heptane soluble products by TLC because when a saturating concentration of diolein is achieved in the incubation mixture TAG formation greatly exceeds cholesterol ester synthesis (Rodriguez, M.A., and Lau, T.E. unpublished results).

Kinase activity was assayed by measuring the incorporation of ${ }^{32} \mathrm{P}$ from ${ }^{32} \mathrm{P}$. $\gamma$-ATP into either microsomes or the tyrosine kinase synthetic-peptide substrate (96). Phosphorylation of microsomes was carried out in a total volume of $0.1 \mathrm{~mL}$ containing $50 \mathrm{mM}$ Tris- $\mathrm{HCl}(\mathrm{pH} 7.5), 10 \mathrm{mM} \mathrm{MgCl}, 1 \mathrm{mM}$ DTT, $1 \mathrm{mM}{ }^{32} \mathrm{P}-\gamma-$ ATP $(40 \mathrm{Ci} / \mathrm{mole})$, and microsomes $(30 \mu \mathrm{g})$. Reaction was initiated by the addition of the kinase sample or, in the case of microsomes containing the endogenous kinase, by the addition of the ${ }^{32} \mathrm{P}-\gamma$-ATP. After an incubation of 5 minutes at $37^{\circ} \mathrm{C}$, $0.22 \mu \mathrm{m}$ pore size filters ( $2 \mathrm{~cm}$ diameter) which were prewashed with $0.5 \mathrm{~mL}$ of 50 $\mathrm{mM}$ phosphate, were blotted with $75 \mu \mathrm{L}$ of the incubation mixture. For microsomes treated with phosphatase, the microsomes retained on the filters were incubated 
with a crude preparation of liver phosphatase $(90 \mu \mathrm{g})$ in a $50 \mathrm{mM}$ Tris- $\mathrm{HCl}(\mathrm{pH} 7.5)$ buffer containing $10 \mathrm{mM} \mathrm{MgCl}_{2}$ in a total volume of $100 \mu \mathrm{L}$ for 5 minutes at room temperature. For all incubations, the reaction was terminated by passing $2.5 \mathrm{~mL}$ of $50 \mathrm{mM}$ phosphate through the filter disc under suction. Discs were dryed and counted in $7 \mathrm{~mL}$ of Universol (ICN).

Phosphorylation of the synthetic peptide was carried out as described by Pike et al. [96] with some minor modifications. The incubation was carried out at $37^{\circ} \mathrm{C}$ in a total volume $20 \mu \mathrm{L}$ containing $100 \mathrm{mM}$ Tris- $\mathrm{HCl}(\mathrm{pH} 7.5), 1 \mathrm{mM}$ DTT, 10 $\mathrm{mM} \mathrm{MgCl}, 1 \mathrm{mM}$ synthetic peptide, $0.5 \mathrm{mM}^{32} \mathrm{P}$ - $\gamma$-ATP. Reaction was initiated by the addition of the kinase sample and terminated after 5 minutes by the addition of $30 \mu \mathrm{L}$ of $5 \%$ trichloroacetic acid. After centrifugation, the supernatants were blotted on P-81 paper which was prewashed with $5 \mathrm{mM}$ ATP in $50 \mathrm{mM}$ phosphate buffer. The blotted paper was then washed three times with $75 \mathrm{mM}$ phosphoric acid. After drying, the paper was counted in $7 \mathrm{~mL}$ of Universol in an LKB Rack beta scintillation counter.

Protein concentrations were measured by the dye-binding assay of Bradiord (97) using bovine serum albumin as the standard. 


\begin{abstract}
27
SDS-PAGE. SDS-polyacrylamide gel electrophoresis was carried out in a miniprotean gel electrophoresis apparatus (Bio-Rad), under reducing conditions using the discontinous system of Laemmli $(98)$, with $7.5 \%$ and $4.5 \%$ acrylamide resolving and stacking gels. Gels were stained with Brilliant Blue G colloidal (Sigma), dried and, when indicated, exposed to Fuji NIF-RX X-ray film.
\end{abstract}




\section{8 \\ RESULTS}

Localization of the activity responsible for DGAT inactivation. As we have reported previously most of the activity responsible for DGAT inactivation resides in the cytosol[89], however, depending on the microsome preparation and the types of washes performed, a fraction of the activity remains associated with the microsomes. Incubation of microsomes from rat adipose tissue with $0.5 \mathrm{mM}$ ATP results in the partial inactivation of diacylglycerol acyltransferase (DGAT) $(33 \pm 1$ \% ATP-dependent DGAT inactivation) as shown in Figure 3. Interestingly these microsomes contain also an endogenous kinase activity that catalyzes the incorporation of ${ }^{32} \mathrm{P}$ from ${ }^{32} \mathrm{P}-\gamma$-ATP into microsomes. Washing the microsomes with a high salt, high $\mathrm{pH}$ buffer causes the removal of both the ATP-dependent DGAT inactivating activity and the kinase activity. Adipose tissue cytosolic fraction is able to restore both the DGAT inactivating activity and the kinase activity when added to the washed microsomes.

Effect of inhibitors on cylosolic activity. To further characterize the kinase and DGAT inactivating activities, their sensitivity to some protein kinase inhibitors was examined (Figure 4). As we have previously shown, EDTA decreases the level of DGAT inactivation by the cytosol and ATP (89). Concurrently we have found that there is a decrease in the level of phosphorylation of the microsomes (Figure 4). Inhibitors of serine/threonine kinases such as $\mathrm{H} 7(99)$ and the protein inhibitor 
Figure 3. Localization of the activity responsible for DGAT inactivalion. Microsomes $(8 \mu \mathrm{g})$ with and without cytosol $(120 \mu \mathrm{g})$ were incubated in the presence and absence of $0.5 \mathrm{mM}$ ATP for DGAT inactivation, and assayed for DGAT activity, as described in Materials and Methods. The corresponding decrease in DGAT activity caused by ATP incubation is given as mean \pm SEM. For microsomal phosphorylation, microsomes $(30 \mu \mathrm{g})$ with and without cytosol $(60$ $\mu \mathrm{g})$ were assayed for the incorporation of ${ }^{32} \mathrm{P}$-phosphate from ${ }^{32} \mathrm{P}$ - $\gamma$-ATP $(0.5 \mathrm{mM}$, $40 \mathrm{Ci} / \mathrm{mole}$ ) into microsomes as described in Materials and Methods. Results are given in nmole phosphate incorporated/mg microsomal protein. Washed microsomes refers to microsomes washed with a high $\mathrm{pH}$, high salt bulfer as described in Materials and Methods. 
Figure 3. Localization of activity
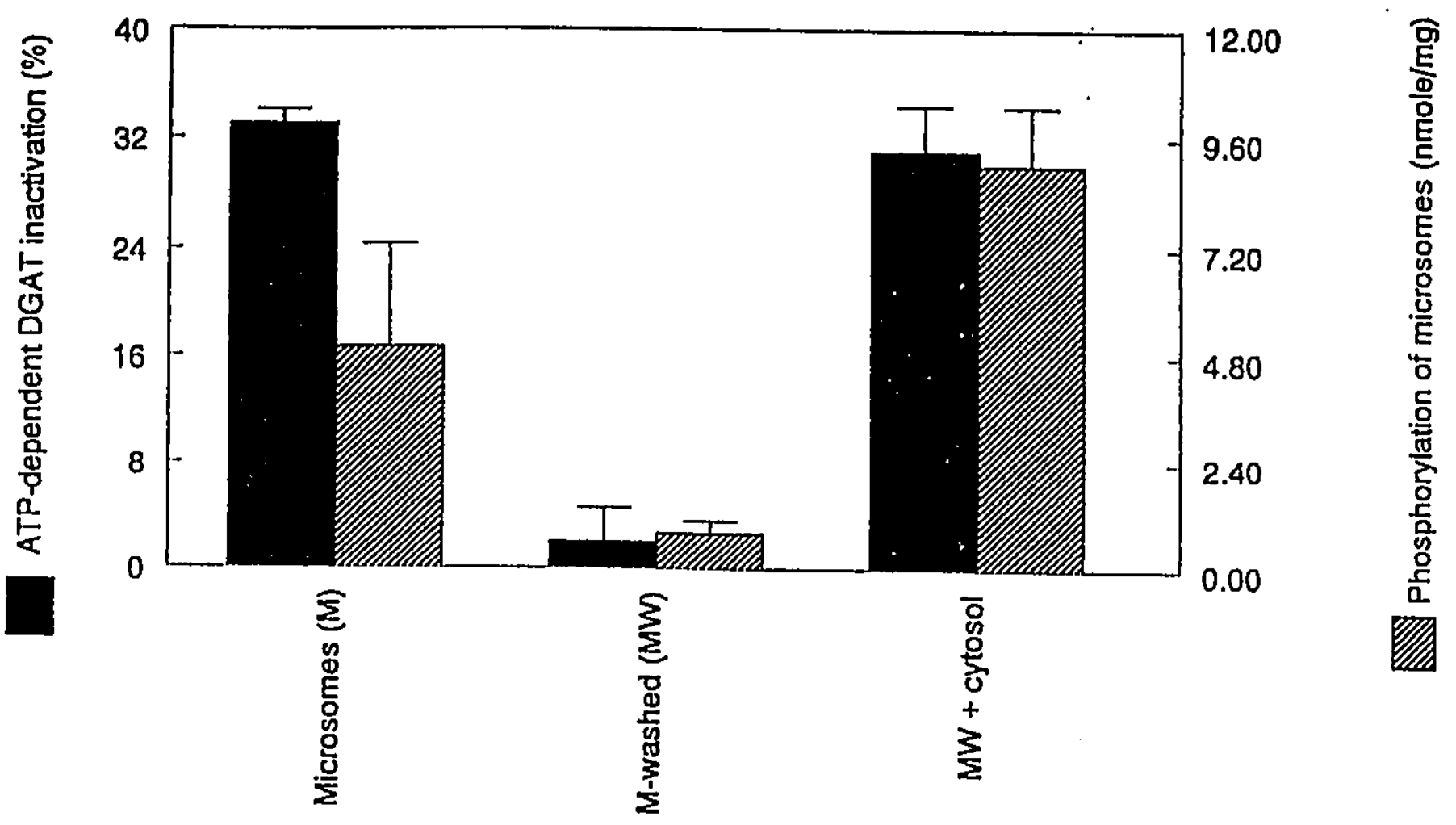
Figure 4. Effect of kinase inhibitors on cytosolic activity. Microsomes with added cytosol and the indicated inhibitor were assayed for DGAT inactivation and for phosphorylation of microsomes as described for Figure 1. "Indicates significant difference $p<0.05$. The $p$ values were calculated using a t-lest with the control (no inhibitor) as reference. 


\section{Figure 4. Effect of kinase inhibitors}

\section{on cytosolic activity}

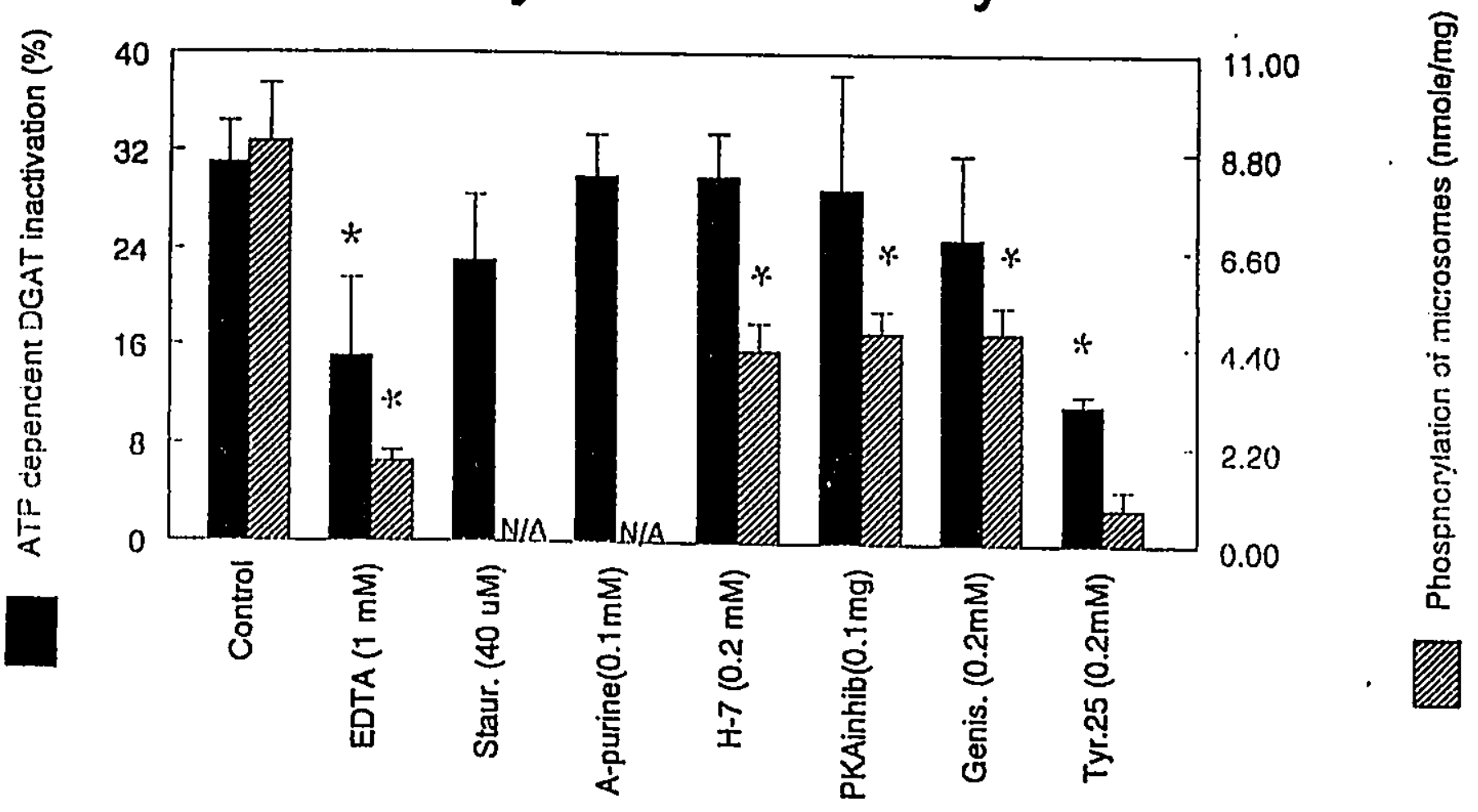


of PKA, did not significantly affect the ATP-dependent inactivation of DGAT, but they did affect the level of phosphorylation in the microsomes, suggesting the presence of cytosolic serine/threonine kinases acting on microsomal proteins other than DGAT. The ATP-dependent DGAT inactivation by the cytosol was also not inhibited by $100 \mu \mathrm{M}$ 2-aminopurine which is an established protein kinase inhibitor with a wide spectrum of inhibition (100). Although staurosoporine was originally thought of as a serine/threonine kinase inhibitor it has also been reported to be an inhibitor of certain tyrosine kinases, including one isolated from rat adipose soluble fraction $(101,102)$. However, we have not observed inhibition of DGAT inactivation with staurosporine. By contrast when tyrphostin 25, a tyrosine kinase inhibitor(99), is present there is a substantial decrease in both the level of ATP-dependent inactivation of DGAT and the level of phosphorylation in microsomes.

Effect of nutritional state on cytosolic activity. DGAT activity and its inactivation by cytosol/ATP was determined in adipose microsomes from rats kept on different diets: starved, fed at libitum, and fed a fat enriched diet. From Table I, the level of microsomal DGAT activity was greatest in the rats kept on latty diets, least in the starved rats, and intermediate with rats fed at libitum which is consistent with what has been reported previously. Levels of ATP dependent DGAT inactivation were not different (all between 35-40\%) between the three groups which could be explained if short term regulation (eg. with hormones) and long term regulation were 


\section{Table I}

\section{Different nutritional states and the corresponding DGAT activity and DGAT inactivation}

\begin{tabular}{|l|l|l|}
\hline Nutritional State & $\begin{array}{l}\text { DGAT activity } \\
\text { (nmole/min/mg) }\end{array}$ & $\begin{array}{l}\text { ATP-dependent } \\
\text { DGAT } \\
\text { inactivation (\%) }\end{array}$ \\
\hline Starved & $4.9 \pm 0.9$ & $33 \pm 6$ \\
\hline Fed at libitum & $6.9 \pm 0.8$ & $31 \pm 3$ \\
\hline Fed fatty diet & $9.2 \pm 0.6$ & $35 \pm 3$ \\
\hline
\end{tabular}

"Male sprague dawley rats ( 4 per group) were kept on three different diet regimes: starved rats were deprived of food for $48 \mathrm{hrs}$; rats fed at libitum had free access to their regular diets; and rats fed on a high fatty diet had free access to chow supplemented with corn oil for one week ( $18 \%$ protein, $47 \%$ carbohydrate, $35 \%$ fat). Microsomes from epididymal tissue from rats were prepared as described in Materials and Methods.

'Microsomes ( $8 \mu \mathrm{g}$ protein) with and without cytosol (120 $\mu \mathrm{g}$ protein) from adipose tissue were incubated in the presence and absence of $0.5 \mathrm{mM}$ ATP for DGAT inactivation, and assayed for DGAT activity, as described in Materials and Methods. 


\section{3}

achieved independently and through a different mechanism, or during the process of microsomal and cytosolic isolation the regulated enzymes lose their level of regulation (ie. if regulation is achieved by phophorylation-dephosphorylation then the enzymes may become dephosphorylated). The former is partially true in view of cell function and the importance of TAG synthetic enzymes in adipose tissue, since the long term regulation would likely involve increase in protein synthesis relative to the constititively expressed genes which would explain the observed increase in specific activity (Table 1). If the latter is true then in vitro studies of the effect of the hormone may be difficult to access because its action may involve phosphorylation of the regulated enzymes which may be reversed in the process of isolation of the enzyme activities, unless specific phosphatase inhibitors were found.

Cytosolic activity from liver vs adipose tissue. Cross inactivation of microsomes from adipose and liver tissues with cytosolic fractions from adipose and liver tissues (Table II) demonstrates that optimal inactivation is achieved by fractions from the same tissue. This suggests that either the enzymes from different tissues may represent differing isoforms with alternate specificities or the enyzmes are regulated in different manner as would be expected since adipose and liver tissue are regulated inversely. In fact, we have found evidence that some of the TAG synthetic enzymes of liver and adipose tissue may be different isoforms 


\section{Table II}

\section{Cross inactivation of DGAT from adipose and liver tissue fractions}

\begin{tabular}{|c|c|c|}
\hline & \multicolumn{2}{|c|}{ DGAT Inactivation $^{\mathrm{a}}(\%)$} \\
\hline \multirow[t]{2}{*}{ Cytosol } & \multicolumn{2}{|c|}{ Microsomes } \\
\hline & Liver & Adipose \\
\hline Liver & $35 \pm 4(3)$ & $11 \pm 1(3)$ \\
\hline Adipose & $12 \pm 1(3)$ & $38 \pm 2(3)$ \\
\hline
\end{tabular}

"Microsomes $(8 \mu \mathrm{g})$ with and without cytosol $(120 \mu \mathrm{g})$ from either liver or adipose tissue were incubated in the presence and absence of $0.5 \mathrm{mM}$ ATP for DGAT inactivation, and assayed for DGAT activity, as described in Materials and Methods. The corresponding decrease in DGAT activity caused by ATP is given as mean \pm SEM for the number of independent experiments indicated in parenthesis. 


\section{5}

because of differences in sensitivity to various inhibitors we have studied (results not shown) (103).

Purification of DGAT inactivating activity. The activity responsible 'for the ATP. dependent inactivation of DGAT was partially purified from the cytosol by a sequence of steps involving a $55 \%$ ammonium sulfate precipitation and Blue Sepharose, S-sepharose, DEAE-sepharose, and Sephacryl S-200 chromatographies as described in "Materials and Methods" and summarized in Figure 5. Other columns that were attempted but were inefficient in resolving activity from protein were hydroxyl-appatite, AMP-sepharose, phosphocellulose, histone-agarose, and sephadex G-75 (results not shown). The protein elution profiles for the purification sequence, in addition to the level of DGAT inactivation are given in Figures 6-9. From figure 6, the majority of the activity responsible for inactivating DGAT is associated with the protein peak which elutes at $0.3 \mathrm{M} \mathrm{NaCl}$ although some activity is associated with the $1 \mathrm{M}$ peak. At each step, with the exception of the Sephacryl column, using the capacity to inactivate DGAT to follow the activity the chromatographic columns were able to resolve the activitiy from other protein peaks without activity, with the majority of the activity binding to Blue Sepharose (Figure 6), S-Sepharose (Figure 7) and DEAE sepharose (Figure 8) and coelutes with the protein peaks at $\mathrm{NaCl}$ concentrations of $0.3,0.5$ and $1.0 \mathrm{M}$ respectively. In the case of the gel filtration column (Figure 9), the protein elutes 
Figure 5. Flowchart of the purification sequence. Rat epididymal tissue was homogenized and applied to a purification sequence as described in Materials and Methods. Purification factors calculated based on protein recovery are indicated in parenthesis. 


\section{Figure 5. Flowchart of the Purification Sequence.}

Rat adipose tissue homogenates

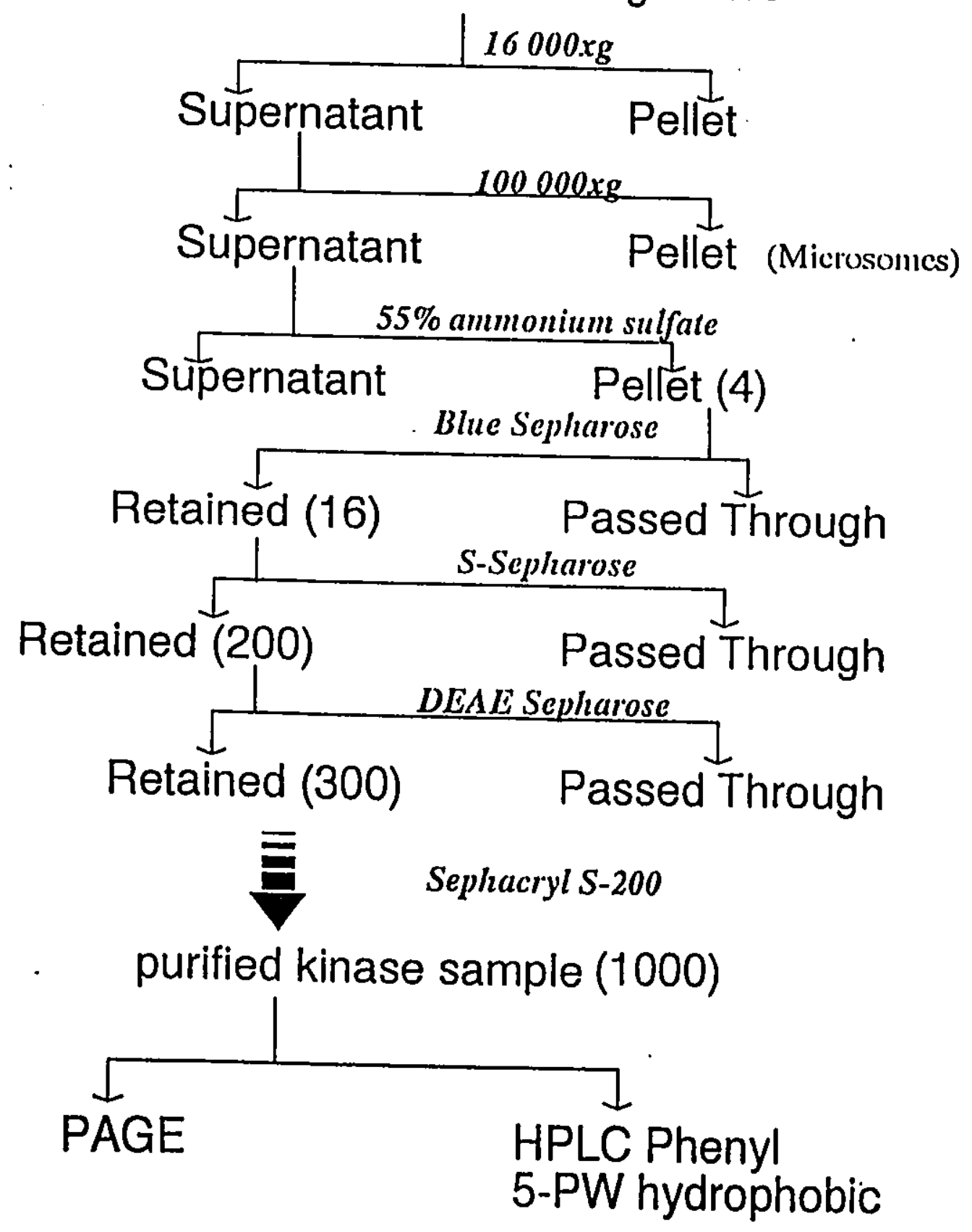


Figure 6. Elution profile for the blue Sepharose column. The pellet $(38 \mathrm{mg})$ from the $55 \%$ ammonium sulfate precipitation was resuspended in TED buffer and applied to a $30 \mathrm{~mL}$ of blue Sepharose column followed by a step elution of TED buffer containing $0,0.3$ amd $1 \mathrm{M} \mathrm{NaCl}$. Fractions were assayed for protein content. Pools were made of the protein peaks as indicated by the bar diagrams and assayed for DGAT inactivation as described in Materials and Methods by incubating the pooled fractions with washed microsomes and with the DGAT subsirates in the presence and absence of ATP. The percentage decrease in activity caused by the addition of ATP is given. 


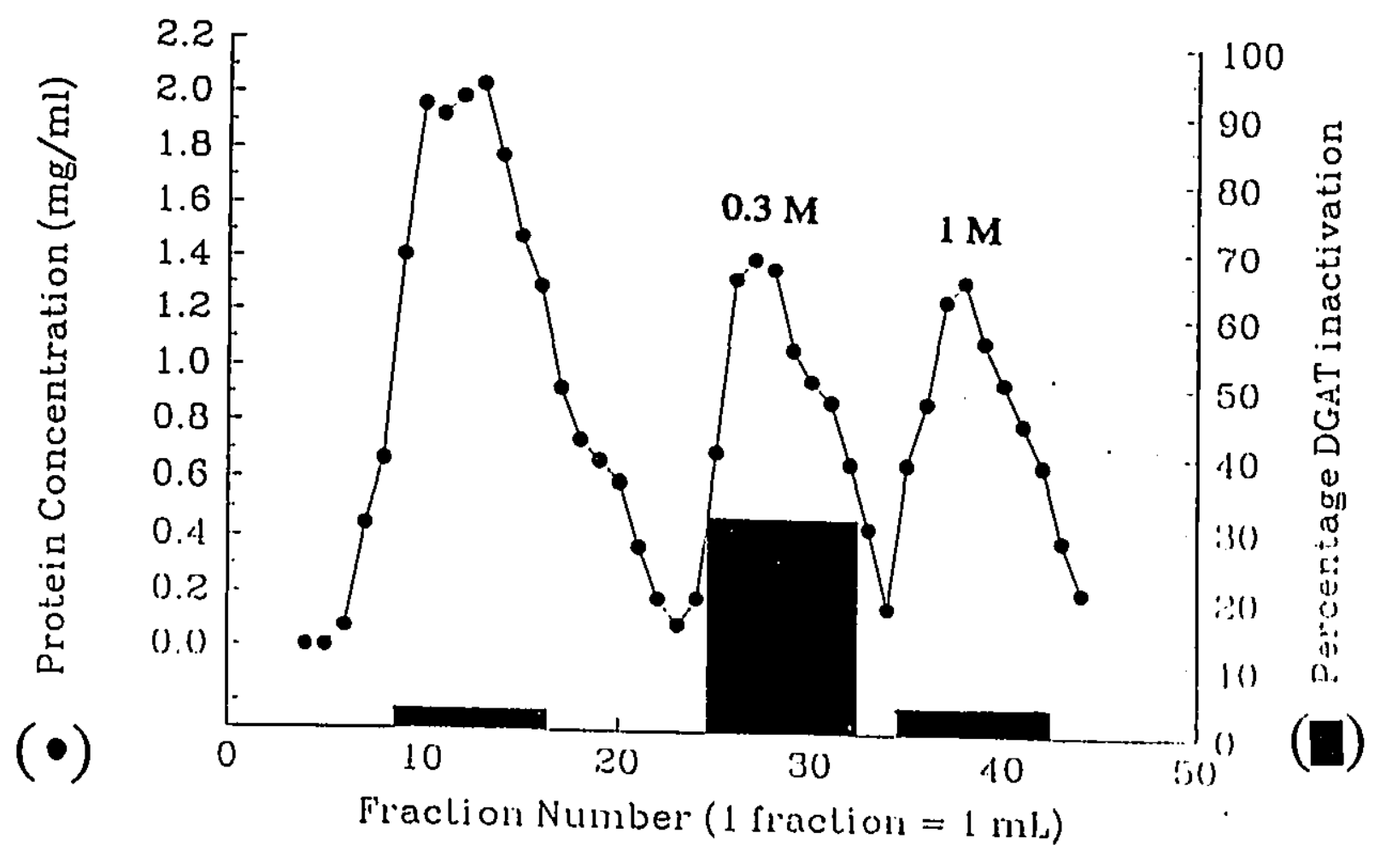

\section{Figure $6 . \quad$ Elution profile for the blue sepharose column.}


Figure 7. Elution profile for the S-Sepharose column. The protein peak $(9.4 \mathrm{mg})$ which eluted at $0.3 \mathrm{M} \mathrm{NaCl}$ from the previous column was pooled and dialyzed against TED buffer and applied to a $20 \mathrm{~mL}$ S-Sepharose column and eluted in step wise fashion with 0 , and $0.5 \mathrm{M} \mathrm{NaCl}$ in TED buffer. DGAT inactivation was assayed with the pooled fractions $8-11,19-21$ as described in Figure 6. 


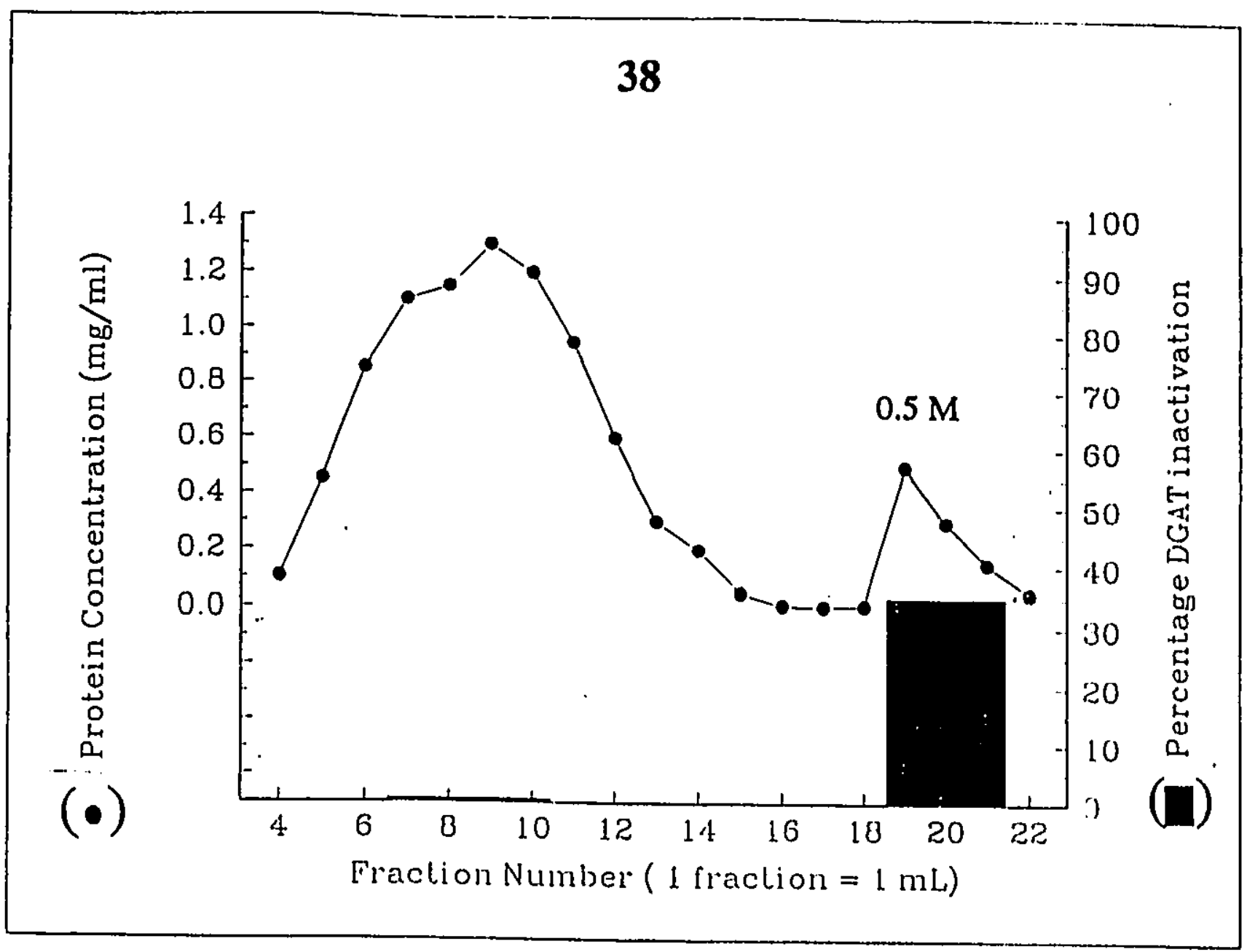

\section{Figure 7. Elution profile for the s- sepharose column.}


Figure 8. Elution profile for DEAE sepharose. The protein peak/pooled fraction $(0.570 \mathrm{mg})$ which eluted at $0.5 \mathrm{M} \mathrm{NaCl}$ in TED buffer from the S-sepharose column was dialyzed against TED and applied to a $7 \mathrm{~mL}$ DEAE sepharose column and eluted with $1 \mathrm{M} \mathrm{NaCl}$ in TED. DGAT inactivation was assayed with the pooled fractions 6-10, 14-16, and 20-21 as described in Figure 6. 


\section{9}

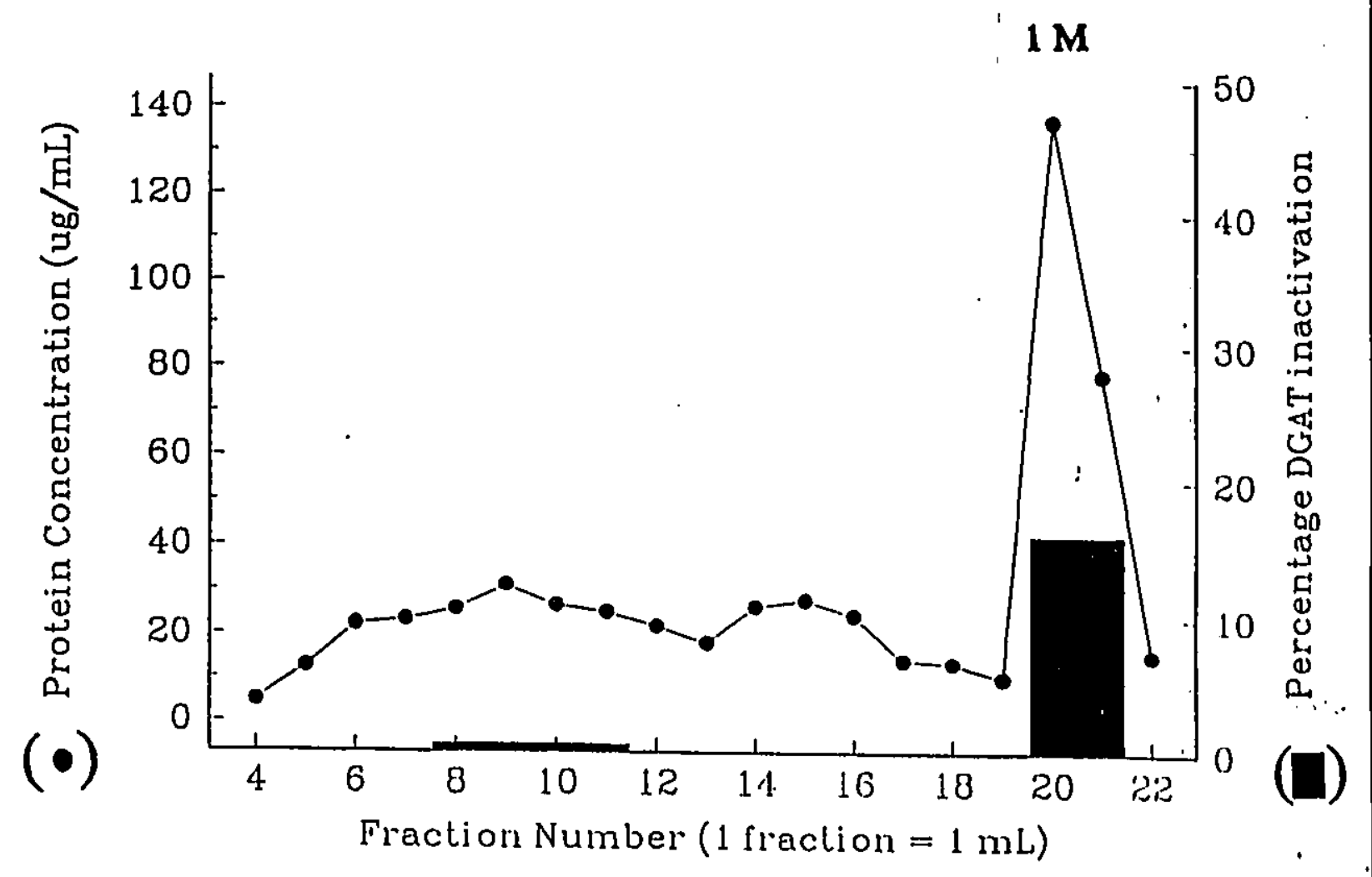

Figure 8.

\section{Elution profile for the DEAE- sepharose column.}


Figure 9. Elution profile for the Sephacryl column. The pooled fraction/protein peak $(0.29 \mathrm{mg})$ which eluted from the DEAE Sepharose column was applied to a $45 \mathrm{~cm}$ Sepharcryl column equilibrated with TED buffer. DGAT inactivation was assayed with fractions 11 , pooled fractions $12-15$, and fraction 16 as described in Figure 6. 
40

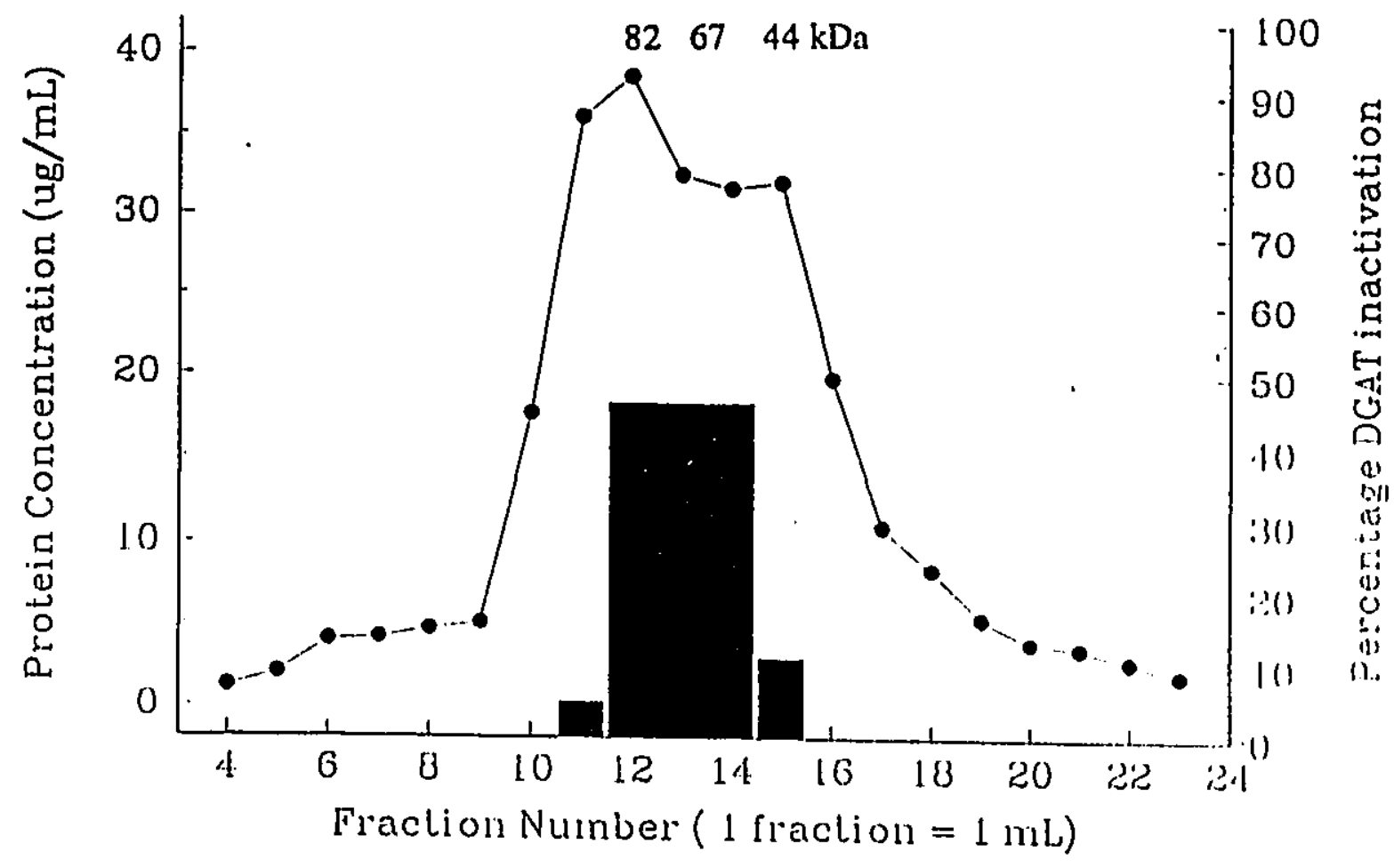

Figure 9. Elution profile for the
Sephacryl column. 


\section{1}

in two overlapping peaks corresponding to 82 and $44 \mathrm{kDa}$, with the pool of activity centered at $67 \mathrm{kDa}$. The final fraction containing the activity represented less than $0.1 \%$ of the starting protein.

During one of several previous attempts at the purification of the DGAT inactivating activity a sequence of chromatographic steps was run under conditions similar to those described above but a phosphocellulose column was substituted for the S-sepharose column. The level of purification achieved as determined by protein recovery was less than $300 x$. The final pool which contained the activity responsible for DGAT inactivation was analyzed for purity by a HPLC Bio-Gel TSK Phenyl 5-PW hydrophobic Bio RAD column. After several runs we were able to partially resolve two peaks as shown in Figure 10. As a diagnostic tool suggesting we had two or more polypeptides in our final pool, we attempted to separate the two polypeptides in a more efficient purification sequence. As a consequence, the S-sepharose column was substituted for the phosphocellulose anion exchanger to achieve a more efficient purification.

Previously, in an attempt to follow protein kinase activity throughout our purification, an assay was developed for kinases employing the phosphorylation of a mixture of histones (Calbiochem, San Diego, C.A.) by ${ }^{32}$ P- $\gamma$-ATP followed by binding of the products to phosphocellulose paper (Whattman p-81) (results not 
Figure 10. HPLC Analysis of sephacryl pool of DGAT inactivating activity. High performance liquid chromatography column was a Bio-Gel TSK Phenyl 5-PW hydrophobic Bio RAD column. The kinase sample $(50 \mu \mathrm{g})$ was prepared by concentration of the final pool of the sephacryl column by dialysis with polyetheylene glycol to a concentration of $100 \mu \mathrm{g} / \mathrm{mL}$ and applied to the column followed by a $1 \mathrm{M}$ to $10 \mathrm{mM}$ ammonium phosphate gradient to achieve maximal resolution of the peaks. 


\section{Figure 10. HPLC analysis.}

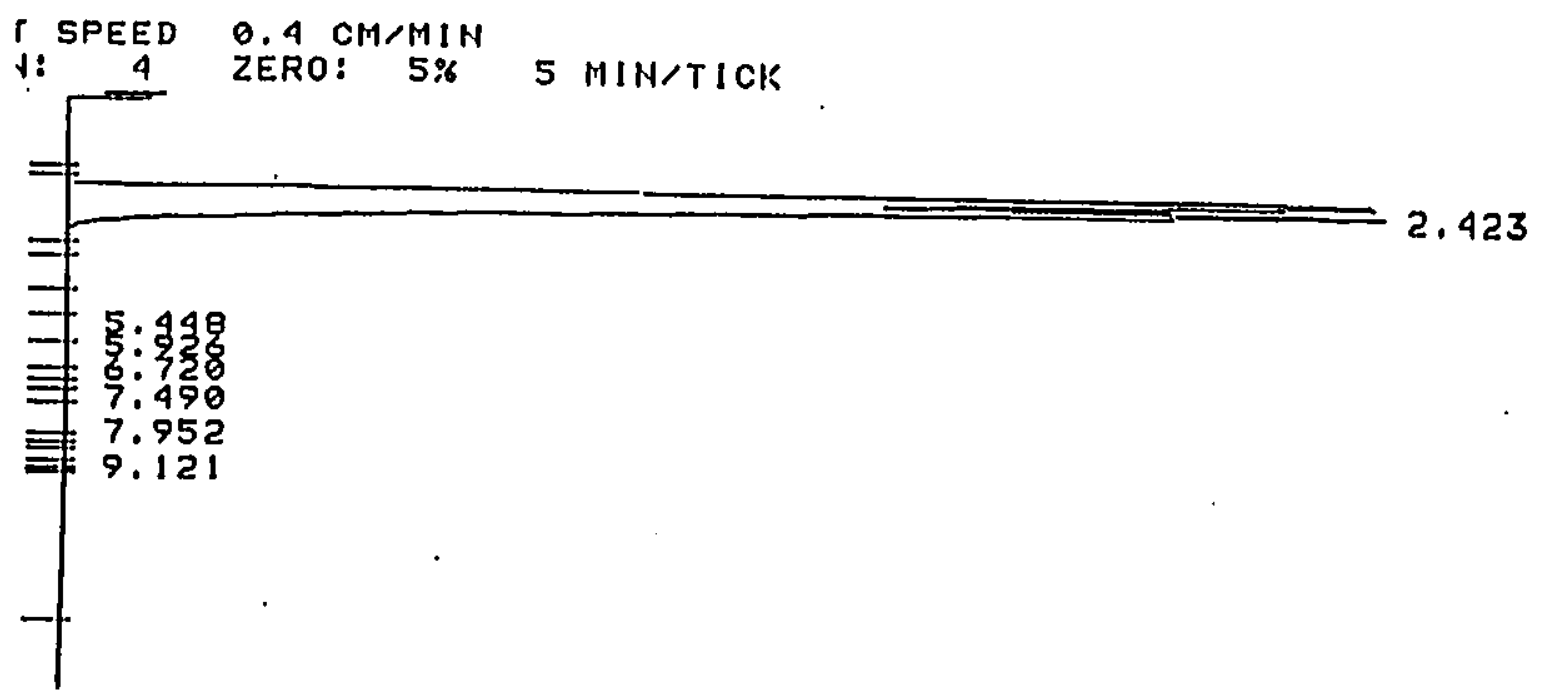




\section{3}

shown). During the process of the purification of the activity responsible for inactivating DGAT the histone phosphorylation did not coincide with the protein pools corresponding to DGAT inactivating activity at each chromatographic step of the purification. This indicated that histones, which are good substrates for several ser/thr kinases, were not good substrates of our kinase activity.

Our later results with a tyrosine kinase substrate suggested an explanation; our cytosolic fraction preparations may contain a tyrosine kinase activity and hence did not phosphorylate either the mixture of histones (or caseine) appreciably. Indeed, the activity which was responsible for inactivating DGAT was shown to copurify at each step with a kinase activity as measured with a non-specific assay for tyrosine kinases employing a synthetic peptide. From Table III the specilic activity of tyrosine phosphorylation went from 0.48 to 74 pmoles phosphate incorporated into the peptide per $\mu \mathrm{g}$ microsomal protein, an increase of approximately $150 x$, from the pellet of the ammonium sulfate precipitation to the final pool of the sephacryl column. Reducing SDS-PAGE of the purified traction shows a single major band at about $68 \mathrm{kDa}$ (see Figure 11).

Characterization of the purified kinase. By measuring the level of phosphorylation of microsomes it became evident that the final pool of the purification has kinase activity ( $6 \pm 1.7 \mathrm{nmole}$ phosphate incorporated/mg microsomal protein) (Table IV). 


\section{Table III}

Purification sequence of the kinase associated with DGAT inactivation.

\begin{tabular}{|l|l|l|l|l||}
\hline \hline Purification Step & $\begin{array}{l}\text { Total } \\
\text { Protein } \\
(\mathrm{mg})\end{array}$ & \multirow{2}{*}{$\begin{array}{l}\text { DGAT } \\
\text { inactivation } \\
(\%)\end{array}$} & \multicolumn{2}{|l|}{$\begin{array}{l}\text { Protein Tyrosine Kinase } \\
\text { Activity }\end{array}$} \\
\cline { 3 - 5 } & & $\begin{array}{l}\text { Total } \\
\text { Activity } \\
\text { (pmoles) }\end{array}$ & $\begin{array}{l}\text { Specific } \\
\text { Activity } \\
\text { (pmoles/pg) }\end{array}$ \\
\hline \hline Cytosol & 150 & 31 & 149 & 0.991 \\
\hline $\begin{array}{l}55 \% \text { Ammonium } \\
\text { Sulfatc }\end{array}$ & 37.5 & 49 & 18 & 0.475 \\
\hline $\begin{array}{l}\text { Bluc Sepharose } \\
0.3 \mathrm{M} \mathrm{NaCl}\end{array}$ & 9.38 & 31 & 26 & 2.81 \\
\hline $\begin{array}{l}\text { S-Sepharose } \\
0.5 \mathrm{M} \mathrm{NaCl}\end{array}$ & 0.57 & 35 & 10 & 17.6 \\
\hline $\begin{array}{l}\text { DEAE } \\
1 \mathrm{M} \mathrm{NaCl}\end{array}$ & 0.29 & 13 & 9 & 31.8 \\
\hline Sephacryl & 0.14 & 46 & 10 & 74.0 \\
\hline
\end{tabular}

inactivation in the presence and absence of ATP.

${ }^{b} F$ ractions from the purification steps were assayed for tyrosine kinase activity with the synthetic peptide as described in Methods.

'Results are expressed as pmoles phosphate incorporated into the synthetic peptide for the total amount of the cytosolic fraction.

${ }^{d}$ Results are expressed as pmoles phosphate incorporated into the synthetic peptide per $\mu \mathrm{g}$ of protein (cytosolic fractions). 
Figure 11. Partial purification of the activity responsible for DGAT inactivation. SDS-PAGE was run with $80 \mu \mathrm{g}$ of the unfractionated cytosol (lane 1) and 10 $\mu g$ of the Sephacryl S-200 pool (lane 2) and the gel stained for protein with Brilliant Blue $G$ colloidal. The number on the right indicates the apparent MW $(\mathrm{kDa})$ of the purified protein. 


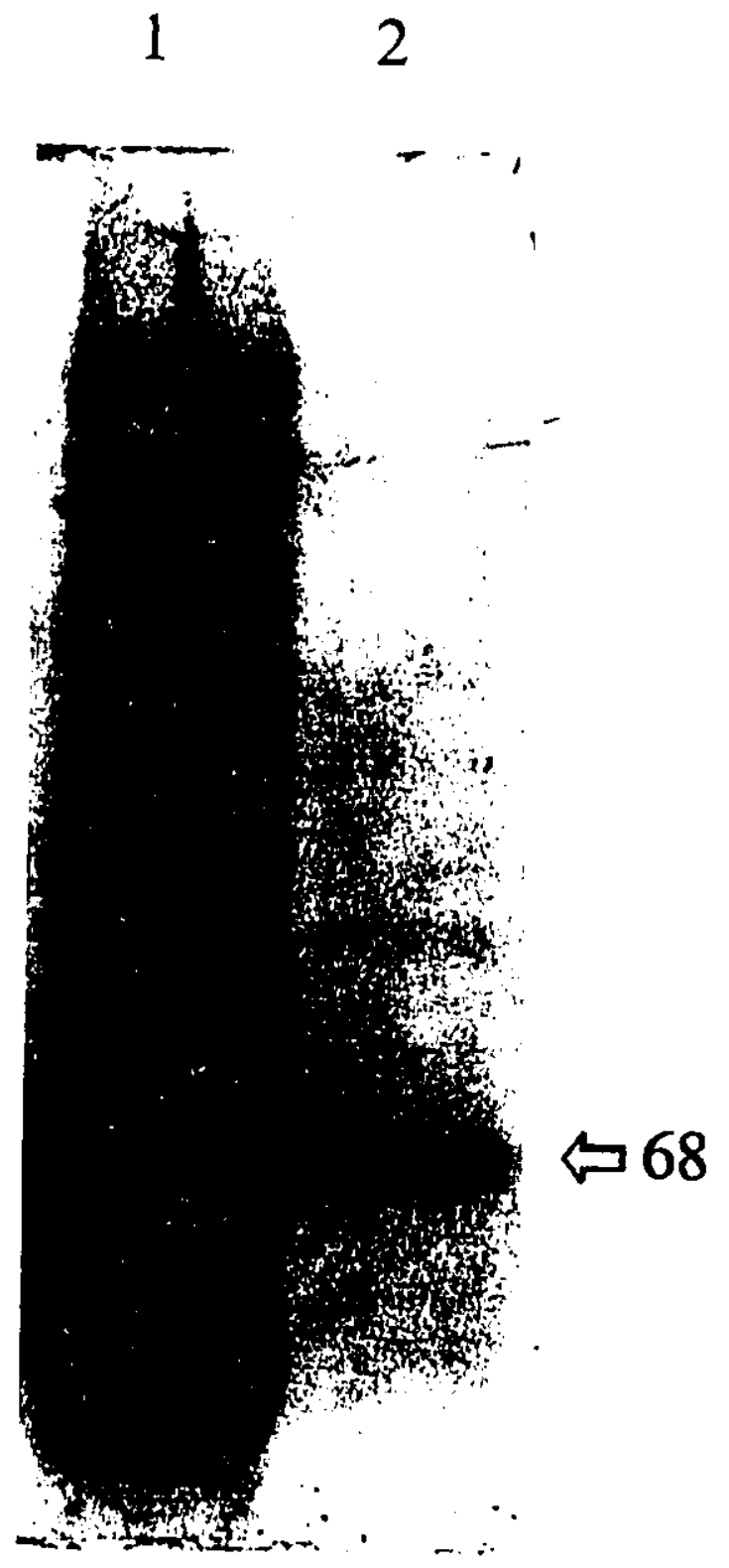

\section{Figure 11. SDS-PAGE of the purified kinase}




\section{Table IV}

\section{Effect of cytosol fractions on different substrates.}

\begin{tabular}{|c|c|c|c|c|}
\hline \multirow{2}{*}{ Addition } & \multirow{2}{*}{$\begin{array}{l}\text { DGAT } \\
\text { inactivationa }_{(\%)}\end{array}$} & \multirow{2}{*}{$\begin{array}{l}\text { GPAT } \\
\text { inactivation } \\
(\%)\end{array}$} & \multicolumn{2}{|c|}{ Phosphorylation } \\
\hline & & & $\begin{array}{l}\text { :1icrosomal } \\
\text { proteins" } \\
\text { (pmole/mg } \\
\text { protein) }\end{array}$ & $\begin{array}{l}\text { Symlhetic } \\
\text { peptidec } \\
\text { (pmole/pg } \\
\text { protein) }\end{array}$ \\
\hline Control & $6 \pm 4.7(3)$ & $7.3 \pm 4.5(3)$ & $1 \pm 0.3$ & $\begin{array}{l}(25 \pm 14) \times 10^{-5} \\
(3)\end{array}$ \\
\hline Cytosol & $31 \pm 3.4(6)$ & $38 \pm 5(9)$ & $9 \pm 1.3(4)$ & $0.99 \pm 0.15(8)$ \\
\hline $\begin{array}{l}\text { Purified } \\
\text { kinase }\end{array}$ & $46 \pm 3.8(8)$ & $34.3 \pm 3.5(3)$ & $6 \pm 1.7(4)$ & $74.0 \pm 0.1$ \\
\hline
\end{tabular}

a Microsomes were assayed for DGAT and GPAT inactivation as described in Methods in the presence of either $1.2 \mu \mathrm{g}$ of the purified kinase or $20 \mu \mathrm{g}$ of the S-sepharose flow through fraction (control).

${ }^{b}$ Microsomes were assayed for phosphorylation as described in Methods in the presence of either $60 \mu \mathrm{g}$ cytosol, $10 \mu \mathrm{g}$ control, or $100 \mathrm{ng}$ purified kinase.

${ }^{c}$ The purified kinase ( $165 \mathrm{ng}$ average) and $5 \mu \mathrm{g}$ of the S-sepharose flow through fraction (control) were assayed for tyrosine kinase activity as described in Methods. 


\section{7}

Again, as for the cytosol, this kinase activity is almost completely blocked by tyrphostin 25, and to a lesser degree by genistein (Figure 12), which are both tyrosine kinase inhibitors (99). By contrast, the kinase preparation is less sensitive to inhibition by $\mathrm{H} 7$, suggesting that most of the serine/threonine kinases present in the cytosol have been removed. Additionally, the ATP dependent DGAT inactivation by the sephacryl pool is prevented by genistein and tyrphostin 25 but not by $\mathrm{H7}$, although the effect of genistein is now more apparent than with the cytosol (Figure 12). Furthermore, our preparation is also able to phosphorylate the synthetic peptide Arg-Arg-Leu-Ile-Glu-Asp-Ala-Glu-Tyr-Ala-Ala-Arg-Gly which is a specific substrate of protein tyrosine kinases (96) (Table III and IV). Since we have previously shown that microsomal GPAT is also reversibly inactivated by an ATP-dependent activity in rat adipose cytosol (87), we determined whether or not the activity purified from the cytosol, as followed by DGAT inactivation, could inactivate GPAT in vitro. From Table IV it is apparent that the partially purified kinase preparation is capable of inactivating GPAT in the presence of ATP. As shown for the phosphorylation of the synthetic peptide, the flow-through fractions of S-sepharose column, which were unable to inactivate DGAT were also unable to inactivate GPAT significantly. 
Figure 12. Effect of kinase inhibitors on the purified kinase. Microsomes were assayed for DGAT inactivation and phosphorylation of microsomes in the presence of different inhibitors as described in Figure 4 but purified kinase (final concentration, $2.4 \mu \mathrm{g} / \mathrm{mL}$ ) substituted for cytosol. 
Figure 12. Effect of kinase inhibitors on the purified kinase

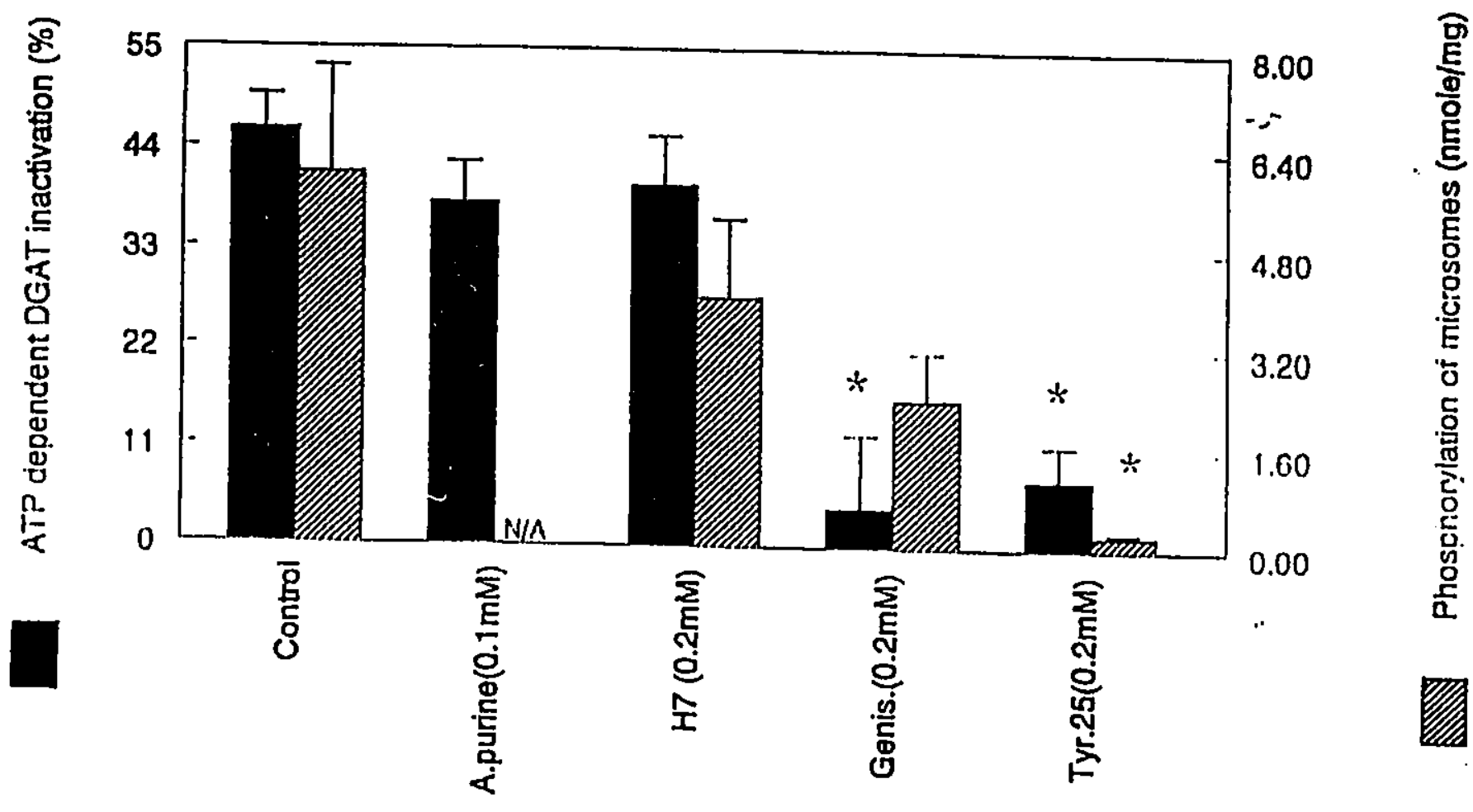


Phosphorylation of microsomal proteins and SDS PAGE. Figure 13 shows the autoradiograph of ${ }^{32} \mathrm{P}$-phosphorylated microsomal proteins run on SDS.PAGE. Two major bands at $53 \pm 1.3$ and $69 \pm 1.1 \mathrm{kDa}$ (average of four gels) are visible as well as a third one at the top of the resolving gel which may represent an aggregate of proteins. Other minor bands are also visible in the regions of 40 and $100 \mathrm{kDa}$. Addition of our purified kinase to the incubation medium results in increased phosphorylation of all bands, and this effect is largely prevented if the inhibitor tyrphostin 25 is present in the incubation. The fact that the addition of the kinase and the inhibitor does not change the pattern of phosphorylated bands in the microsomes suggests that the endogenous kinase activity remaining in our microsomal preparation is the same tyrosine kinase that is present in our purified fraction. Surprisingly, when the purified kinase (Figure 14-lane 2) or a previous fraction of the sequential purification sequence, the S-sepharose pool (Figure 14lane 3), was incubated with ${ }^{32}$ P- $\gamma$-ATP and run on SDS-PAGE followed by autoradiography, no phosphorylated bands were apparent, suggesting that the enzyme does not autophosphorylate. However a similar incubation with the cytosol exhibited multiple phosphorylated proteins including a protein of the same molecular weight $(68 \mathrm{kDa})$ as the protein from the purified fraction suggesting that in the presence of other proteins (perhaps other kinases in the phoshorylation cascade), our purified kinase may be phosphorylated (Figure 14). From lane 4 and 5 of Figure 14, which represent the phosphorylation of microsomes by two 
Figure 13. Phosphorylation of microsomal proteins. Phosphorylation of microsomes was carried out by incubating microsomes $(20 \mu \mathrm{g})$ in a $50 \mathrm{mM}$ Tris- $\mathrm{HCl}$ (pH 7.5), $1 \mathrm{mM} \mathrm{DTT}, 10 \mathrm{mM} \mathrm{MgCl}{ }_{2}$ buffer with ${ }^{32} \mathrm{P}-\gamma-\mathrm{ATP}(0.375 \mathrm{mM}$, $1 \mathrm{Ci} / \mathrm{mm}$ ole) with and without purified kinase $(0.5 \mu \mathrm{g})$ for $5 \mathrm{~min}$ at $37^{\circ} \mathrm{C}$ and tyrphostin $25(0.2 \mathrm{mM})$ in a total volume of $40 \mu \mathrm{L}$. The reaction was terminated by the addition of $20 \mu \mathrm{L}$ sample buffer ( 3 fold concentration) then incubated at $95^{\circ} \mathrm{C}$ for $4 \mathrm{~min}$. A $50 \mu \mathrm{L}$ aliquot was applied to each lane; Lane 1) control (microsomes alone); lane 2) kinase added; and lane 3) kinase and tyrphostin $25(0.2 \mathrm{mM})$ added. Gels were stained, dried and exposed to Fuji NIF-RX film in an X-ray cassette for 3 days. The numbers on the right indicate the MW $(k D a)$ values of the marker proleins and the numbers on the left the $M W(k D a)$ of the major phosphoproteins labelled. 
50

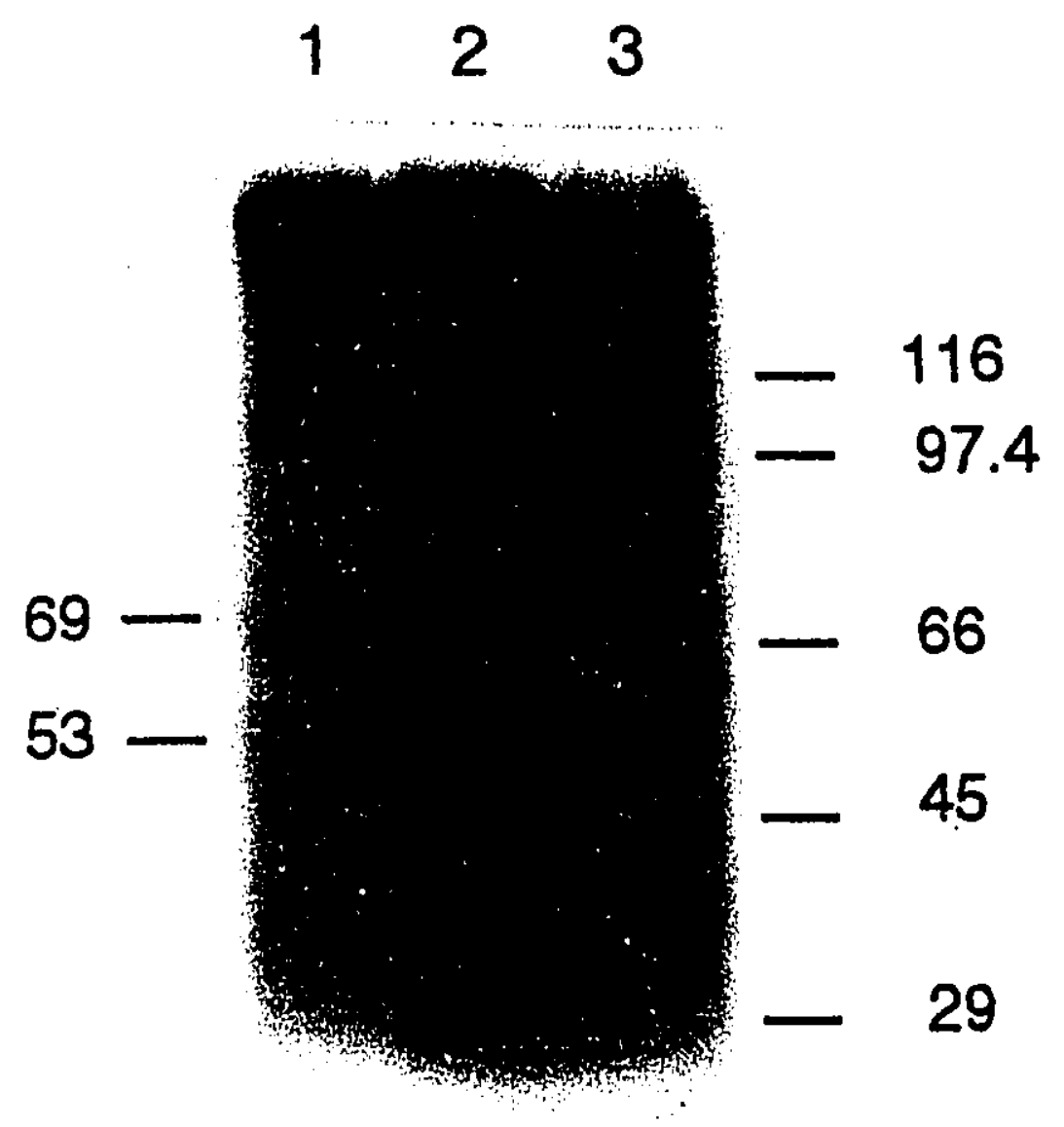

Figure 13. Phosphorylation of microsomal
proteins. 
Figure 14. Protein phosphorylation by different cytosolic fractions. Phosphorylation of proteins was carried out by incubating either microsomes $(20 \mu g)$ or the equivalent amount of buffer A with a kinase sample (cytosolic fractions) in a $50 \mathrm{mM}$ Tris- $\mathrm{HCl}(\mathrm{pH} 7.5), 1 \mathrm{mM} \mathrm{DTT}, 10 \mathrm{mM} \mathrm{MgCl}$ buffer with ${ }^{32} \mathrm{P}-\gamma-\mathrm{ATP}(0.250 \mathrm{mM}, 1 \mathrm{Ci} / \mathrm{mmole})$ for $5 \mathrm{~min}$ at $37^{\circ} \mathrm{C}$ in a total volume of $40 \mu \mathrm{L}$. The reaction was terminated by the addition of $20 \mu \mathrm{L}$ sample buffer ( 3 fold concentration) then incubated at $95^{\circ} \mathrm{C}$ for $4 \mathrm{~min}$. A $50 \mu \mathrm{L}$ aliquot was applied to each lane; Lane 1) cytosol alone $(50 \mu \mathrm{g})$; lane 2) S-sepharose pool alone (10 $\mu g)$; lane 3) Sephacryl pool alone (10 $\mu \mathrm{g})$; lane 4) microsomes with cytosol (20. $\mu g)$; lane 5) microsomes with the S-sepharose pool (2 $\mu g)$; lane 6) microsomes. with Sephacryl pool $(2 \mu g)$; lane 7) microsomes alone. Gels were stained, dried and exposed to Fuji NIF-RX film in an X-ray cassette for 3 days. 


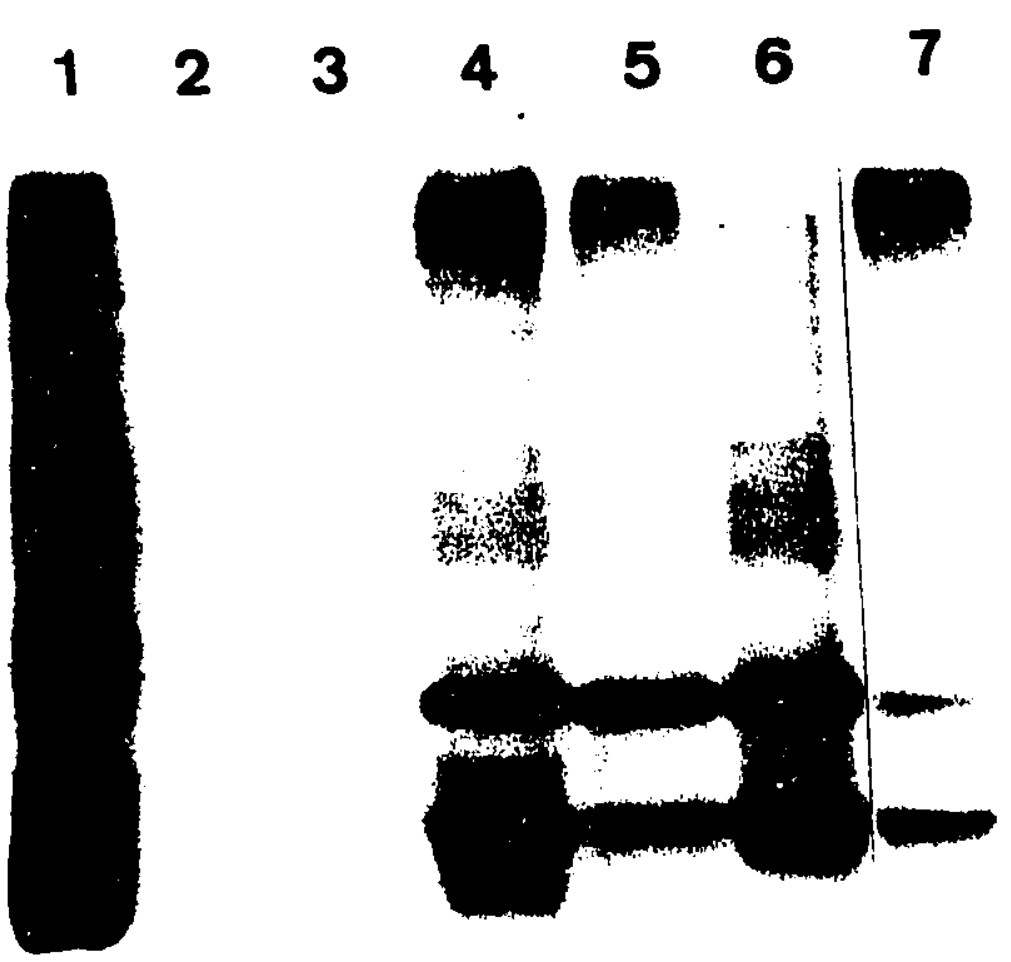

Figure 14. Protein phosphorylation by
cytosolic fractions. 


\section{2}

diflerent fractions of the purification sequence, it is apparent that the kinase activities present in the two fractions may exhibit different microsomal substrate specificity.

Phosphatase experiments. We have previously reported that cytosol/ATP dependent inactivation of microsomal GPAT (87) and DGAT (89) activities could be reversed by incubating the inactivated microsomes with a partially purified protein phosphatase from rat liver in the absence of ATP. Our previous attempts at reactivation of adipose DGAT by various cytosolic fractions as described by Haagsman in rat hepatocytes (72) were unsuccessful. The failure may be direct results of the reported phosphatase inhibitors present in adipose tissue $(104,105)$. However it appears that one preparation of cytosol did have a factor which stimulated the activation of DGAT by the protein phosphatase from liver. The factor was determined to have a molecular weight of less than 30000 as determined by membrane filtration but further attempts to purify the factor were unsuccessful since the activity is easily lost. Therefore we decided to reverse the kinase mediated phosphorylation of microsomal proteins by using a phosphatase preparation from liver that was able to reactivate DGAT. From Table $V$ it is shown that the reactivation of DGAT from kinase treated microsomes by the phosphatase preparation is $\mathrm{Mg}^{2+}$ dependent and is inhibited by $1 \mathrm{mM}$ EDTA, $10 \mathrm{mM}$ phosphate, $40 \mathrm{mM} \mathrm{NaF}$, and vanadate but not by the presence of $0.1 \mu \mathrm{M}$ okadaic acid. Since 


\section{Table V}

\section{Inhibition of DGAT reactivation with protein phosphatase}

\begin{tabular}{|l|l|l|l|}
\hline Addition & $\begin{array}{l}\text { DGAT } \\
\text { reactivation } \\
(\% \pm \text { SDM })\end{array}$ & $\begin{array}{l}\text { Reactivation } \\
\text { inhibition }\end{array}$ & $p^{\mathrm{c}}(\%)$ \\
\hline \hline None & $92 \pm 9(4)$ & 0.0 & - \\
\hline $0.1 \mu \mathrm{M}$ okadaic acid & $88 \pm 9(4)$ & $4 \pm 10$ & 11.s. \\
\hline $40 \mathrm{mM}$ NaF & $26 \pm 4(4)$ & $72 \pm 5$ & $<0.001$ \\
\hline $10 \mathrm{mM}$ phosphate & $12 \pm 15(4)$ & $87 \pm 17$ & $<0.01$ \\
\hline $1 \mathrm{mM}$ EDTA & $6 \pm 11(3)$ & $93 \pm 12$ & $<0.01$ \\
\hline $2 \mathrm{mM}$ vanadate & $45 \pm 9(3)$ & $52 \pm 10$ & $<0.05$ \\
\hline
\end{tabular}

Microsomes $(1 \mathrm{mg} / \mathrm{mL})$ were pretreated for $10 \mathrm{~min}$ at room temperature with cytosol $(2.4$ $\mathrm{mg} / \mathrm{mL}$ ) and ATP $(0.5 \mathrm{mM})$ in a $60 \mathrm{mM}$ Tris (pH 7.4), $1 \mathrm{mM} \mathrm{DTT}, 10 \mathrm{uM} \mathrm{BSA}, 5 \mathrm{mM}$ $\mathrm{MgCl}_{2}$. Aliquots of treated microsomes containing from 10-15 ug were incubated for 10 $\min$ at $37^{\circ} \mathrm{C}$ in a similar buffer with and without a crude preparation of liver protein phosphatase as described in Table $V$ in the presence of the indicated inhibitors and 20 UM of carried over ATP, and then assayed for DGAT activity.

"Over the controls with inhibitors and no phosphatase

'Over the control with no inhibitor (92\%)

'From a t-test using the control with no inhibitor as reference. 


\section{4}

vanadate is an inhibitor of tyrosine phosphatases this suggests that the phosphatase which functions antagonistically against our kinase may be of the tyrosine variety (106). The resistance to $0.1 \mu \mathrm{M}$ okadaic acid (Table $\mathrm{V}$ ) and to EGTA, implies that it is neither protein phosphatases 1, 2a, or 2b (107). Furthermore a liver cytosolic fraction enriched with $\mathrm{M} \mathrm{Mg}^{2+}$ dependent, okadaic acid insensitive, phosphatase did not correspond to the activity responsible for DGAT stimulation which led us to believe that the phosphatase was not of the type $2 \mathrm{C}$ (results not shown).

Reversibility of microsome phosphorylation by the liver phosphatase preparation was investigated by pretreatment of washed microsomes with the purified kinase, which stimulated microsomal phosphorylation from $0.8 \pm 0.28$ to $6 \pm 1.7 \mathrm{nmol} / \mathrm{mg}$ microsomes (Figure 15). Incubation of the microsomes retained on the filter with the crude phosphatase preparation, as described under Materials and Methods, reduces the phosphorylation to $0.2 \pm 0.16 \mathrm{nmol} / \mathrm{mg}$ microsomes (Figure 15).

We have observed that if both the purified kinase and liver phosphatase are present in excess with microsomes, in the presence of $1 \mathrm{mM} \mathrm{ATP}$, the kinase is able to overcome the phosphatase resuiting in net inactivation of DGAT and the corresponding increase in microsomal phosphorylation over the control (4.5 vs 0.8 
Figure 15. Reversibility of DGAT inactivation and microsomal phosphorylation. Washed microsomes were assayed for DGAT activity in the presence of the purified kinase in the presence and absence of ATP as described in Figure 10. Microsomal phosphorylation was assayed as described in Figure 4. For the DGAT inactivation of the kinase/phosphatase incubation, after the preincubation of microsomes with the kinase (without the oleoyl-CoA and diolein) the ATP was removed by passing the sample through an Amicon P30 membrane. The microsomes were resuspended in the incubation buffer with $100 \mu \mathrm{g}$ of the crude liver phosphatase preparation and after correction for protein loss on the membrane, DGAT was then assayed. For the microsomal phosphoryiation. microsomes incubated with the purified kinase were relained on the filters and incubated with a crude preparation of liver phosphatase $(90 \mu \mathrm{g})$ in a $50 \mathrm{mM}$ Tris- $\mathrm{HCl}(\mathrm{pH} 7.5)$ buffer containing $10 \mathrm{mM} \mathrm{MgCl}_{2}$ in a total volume of $100 \mu \mathrm{L}$ for 5 minutes at room temperature. For all incubations, the reaction was terminated by passing $2.5 \mathrm{~mL}$ of $50 \mathrm{mM}$ phosphate through the filler disc under suction. Discs were dryed and counted in $7 \mathrm{~mL}$ of Universol (ICN). 
Figure 15. Reversibility of effects
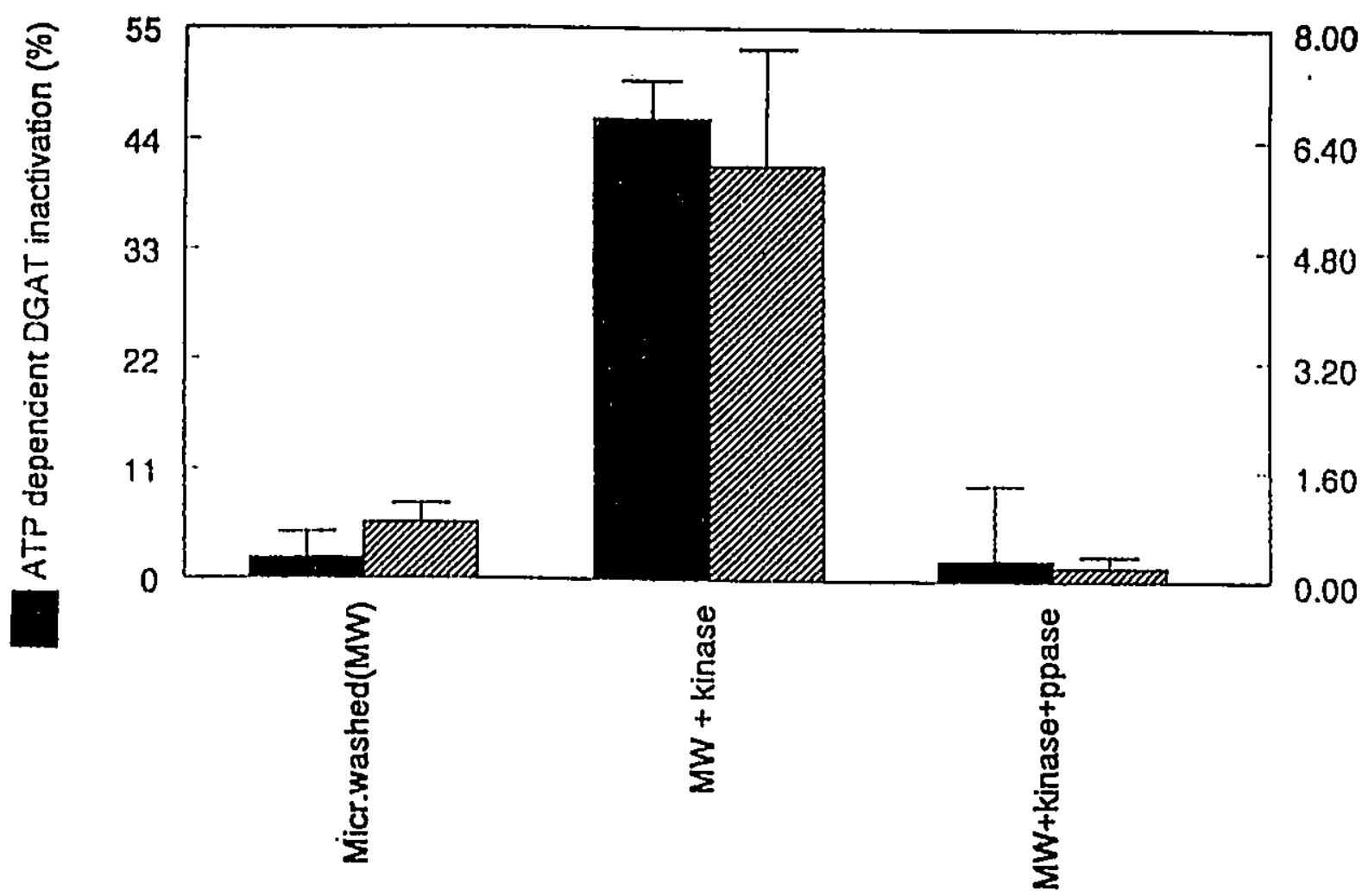

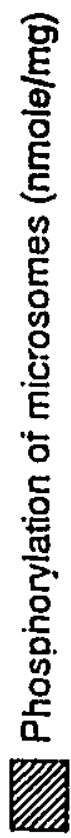




\section{6}

$\mathrm{nmole} / \mathrm{min} / \mathrm{mg}$ ), although not to the levels achieved by the purified kinase acting on microsomes alone $(6.0 \mathrm{nmole} / \mathrm{min} / \mathrm{mg}$ (Figure 15)).

Although a DGAT reactivating phosphatase from adipose tissue has yet to be identified, during the fractionation of the cytosol to purify the kinase, we detected the presence of an activity which stimulated DGAT. This activity was insensitive to okadaic acid but was prevented by $2 \mathrm{mM} \mathrm{ATP}$, and was present in both the $55 \%$ ammonium sulfate pellet and the flow through fraction of the Blue sepharose column (Figure 6) (Lau and Rodriguez unpublished results).

Figure 16 shows the desphoshorylation of phospho proteins from the kinase treated microsomes. Treatment with the kinase stimulated the level of ${ }^{32} \mathrm{P}$. phosphate incorporation into microsomal polypeptides as in Figure 13. Treatment with the liver phosphatase reversed the level of phoshorylation close to control levels (lane 3). 
Figure 16. Phosphatase treatment of kinase phosphorylated microsomal proteins. Phosphorylation of microsomes was carried out by incubating microsomes $(20 \mu \mathrm{g})$ in a $50 \mathrm{mM}$ Tris- $\mathrm{HCl}(\mathrm{pH} 7.5), 1 \mathrm{mM} \mathrm{DTT}, 10 \mathrm{mM} \mathrm{MgCl}$ buffer with ${ }^{32} \mathrm{P}$ - - -ATP $(0.25 \mathrm{mM}, 1 \mathrm{Ci} / \mathrm{mmole}$ ) with (lane 2 and 3 ) and without purified kinase (lane 1) $(0.5 \mu \mathrm{g})$ for $5 \mathrm{~min}$ at $37^{\circ} \mathrm{C}$ in a total volume of $40 \mu \mathrm{L}$. For lane 3, the kinase treated microsomes were then retained on a 30000 molecular weight cut-off membrane and resuspended in a $35 \mu \mathrm{L}$ of a $50 \mathrm{mM}$ Tris- $\mathrm{HCl}$ (pH 7.5), $1 \mathrm{mM} \mathrm{DTT}, 10 \mathrm{mM} \mathrm{MgCl}$, buffer. $5 \mu \mathrm{L}$ of the phosphatase preparation was added to the incubation mixture. The reaction was terminated by the addition of $20 \mu \mathrm{L}$ sample buffer ( 3 fold concentration) then incubated at $95^{\circ} \mathrm{C}$ for $4 \mathrm{~min}$. A $20 \mathrm{\mu g}$ protein aliquot from each incubation mixture was applied to each lane. Gels were stained, dried and exposed to Fuji NIF-RX film in an $X$-ray cassette for 5 days. The numbers on the right indicate the MW $(\mathrm{kDa})$ values of the major phosphoproteins labelled. 


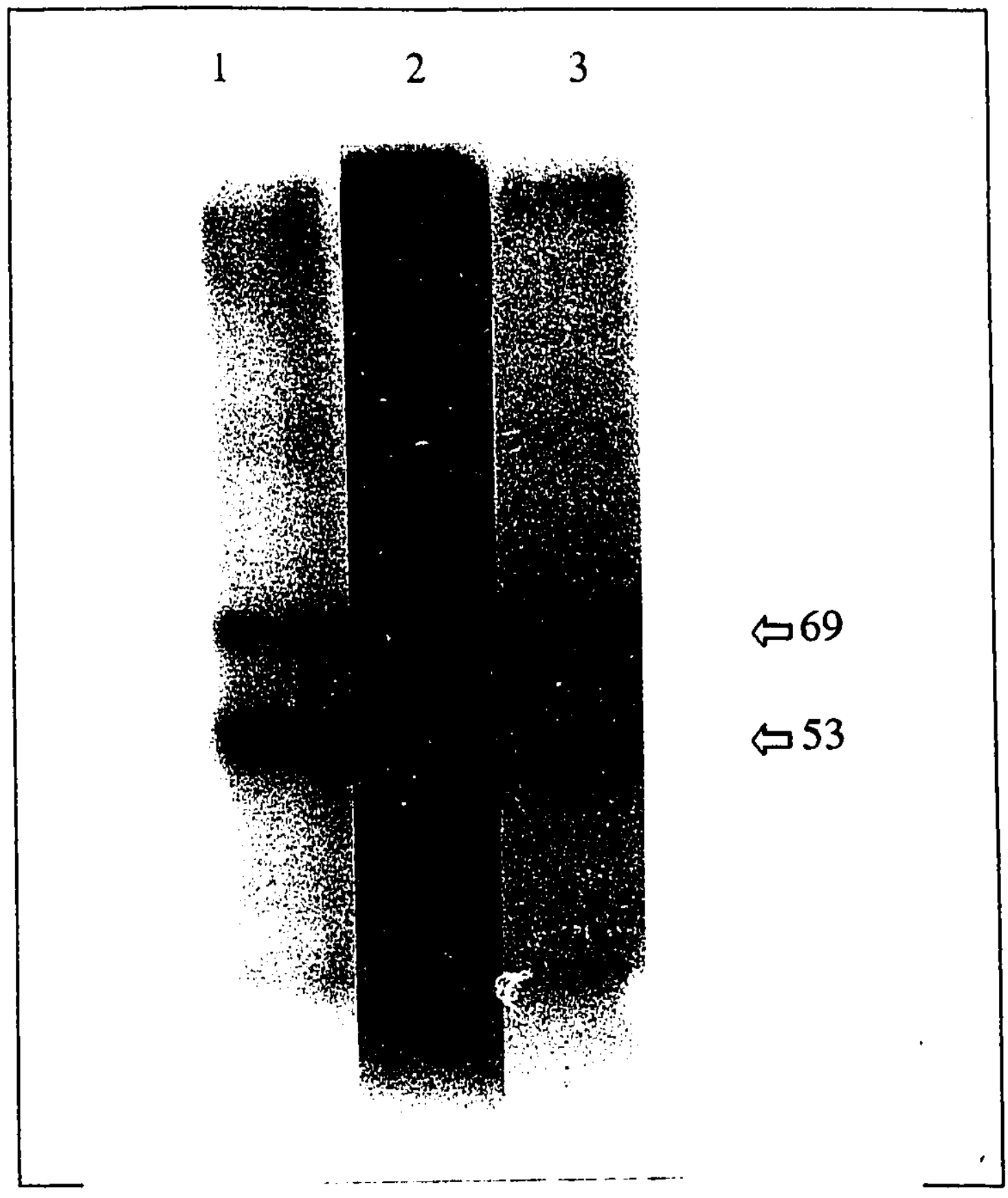

\section{Figure 16. Phosphatase treatment and microsomal phosphorylation.}




\section{8 \\ DISCUSSION}

Our results confirm our previous findings of an ATP-dependent activity present in the cytosol of adipose tissue, which in-vitro reduces both microsomal glycerolphosphate acyltransferase and diacylglycerol acyltransferase activities by $30-40 \%(87,89)$. We have now partially purified that activity from cytosol and found it to run at about $67 \mathrm{kDa}$ on gel filtration (Figure 9) and at $68 \mathrm{kDa}$ on SDSPAGE (Figure 11). It is probably important to note that the calculation of molecular weight from the calibrated gel filtration column may be inaccurate if the molecule is asymmetric, interacts with the gel, or interacts with other proteins. Although electrofocusing or another dimension of PAGE or $\mathrm{N}$-terminal amino acid analysis would better confirm the homogeneity of our preparation, the lact that both SDSPAGE and gel filtration estimation of molecular weight (MW) yield the same result suggests a monomeric enzyme of an approximate MW 67-68 kDa.

Since we measure only; levels and not rates of DGAT inactivation, which probably correspond to maximal changes, we were unable to determine the degree of purification of the DGAT inactivating activity. In an attempt to quantify the activity throughout the purification steps the fractions were assayed for tyrosine kinase activity under conditions of linearity in response to enzyme concentration. Although the specific kinase activity increased by a factor of 150 from the ammonium sulfate precipitation to the final pool the total activity decreased 


\section{9}

significantly from the cytosol to the final pool indicating that other tyrosine kinases unrelated to DGAT inactivation were removed during the process of the purification, especially at the salt precipitation and S-sepirarose steps (Table III). However, according to protein recovery in the final pool, the degree of purification attained is in the order of one thousand fold (Table III). Thus the lack of a quantitative yet specific assay for our enzyme prevents us from an accurate estimation of the degree of purification achieved.

Our hypothesis that the activity responsible for DGAT inactivation in the presence of ATP is a protein kinase is supported by the following observations: 1) the kinase activity, as expressed as the phosphorylation of microsomes, is associated with the DGAT inactivating activity through all of the purification steps, 2) when endogenous microsomal activity responsible for DGAT inactivation is removed by appropriate washing of microsomes, the microsomal phosphorylating activity is concomitantly lost, 3) both activities require $\mathrm{Mg}^{2+}$ and are inhibited by EDTA, 4) DGAT inactivation does not occur when ATP is substituted by $\beta, \gamma$ methylene-ATP (89), 5) both activities are sensitive to the tyrosine kinase inhibitors genistein and tyrphostin 25, and 6) both activities can be reversed by treatment with a crude preparation of protein phosphatase from rat liver. Moreover, our putative DGAT kinase appears to be tyrosine kinase, both because of its sensitivity to established tyrosine kinase inhibitors (genistein and tyrphostin 25) (99) and 


\section{0}

because of its ability to phosphorylate a synthetic peptide which is used as a general artificial substrate of protein tyrosine kinases(96).

Unlike many other protein tyrosine kinases which have been identified, our kinase does not appear to be autophosphorylated since incubation of the kinase with ${ }^{32} \mathrm{P}-\gamma-\mathrm{ATP}$ in the presence of $\mathrm{Mg}^{2+}$ does not result in labelling of the $68 \mathrm{kDa}$ band (Figure 14). It is possible that the kinetics of autophosphorylation are such that dephosphorylation occurs during the incubation and running of the gels. However it is more likely that other kinases in the adipocyte phosphorylate our kinase since a $68 \mathrm{kDa}$ band is radiolabelled in phosphorylation experiments with adipose cytosol alone (Figure 14).

To our knowledge adipose tissue GPAT and DGAT have not yet been purified; therefore we cannot assign any of the phosphorylated bands to either of these two enzymes. DGAT from soybean cotyledons has been found to consist of three different polypeptides of $40.8,28.7$ and $24.5 \mathrm{kDa}$ [108]. However, studies by radiation inactivation of rat liver DGAT suggests that a unit of $68-76 \mathrm{kDa}$ comprising one or more polypeptides is required for activity [109]. It is therefore interesting that one of the major substrates in microsomes of our purified kinases is a polypeptide of approximately $69 \mathrm{kDa}$. Furthermore, it has been suggested that a $54 \mathrm{kDa}$ microsomal polypeptide which is labelled by radioactive iodoacetate but 


\section{1}

is not phosphorylated by PKA, is a component of GPAT (86). This band may correspond to the other major microsomal substrate $(53 \mathrm{kDa})$ of our kinase. However, Escherichia coli GPAT comprises a single polypeptide of 83 kDa (110) and murine mitochondrial GPAT has been recently identified as a $90 \mathrm{kDa}$ polypeptide (111).

One of the effects of insulin is an increase in adipocyte triacylglycerol synthesis, which is not secondary to its effects on lipoprotein lipase, glucose uptake, or fatty acid synthesis (2) (see Figure 17). Although insulin action through its receptor tyrosine kinase activity is well established the search for physiologically relevant phosphorylation substrates and for intracellular cylosolic mediators of signal transduction continues. Experiments indicate that the in vivo phosphorylation of several proteins including pp185 (112) and perilipin from 3T3 adipocytes [113] are insulin dependent. In vitro studies also indicate that the insulin receptor and insulin like growth factor receptor stimulate soluble but nol insoluble protein tyrosine phosphatase activity in a dose dependent fashion in rat skeletal muscle (114). Other studies suggests that diabetes appears 10 induce lissue specific changes in phosphoprotein phosphatase activites (resulting in significant alterations in the dephosphorylation of insulin receptor and glycogen synthase). There appears to be a differential regulation of protein tyrosine phosphatase (PTPase) and protein serine phosphatase (PSPase) activities in diabetes particularly, 


\section{Figure 17. Hypothetical regulation of TAG synthesis in adipose tissue}

Glucose

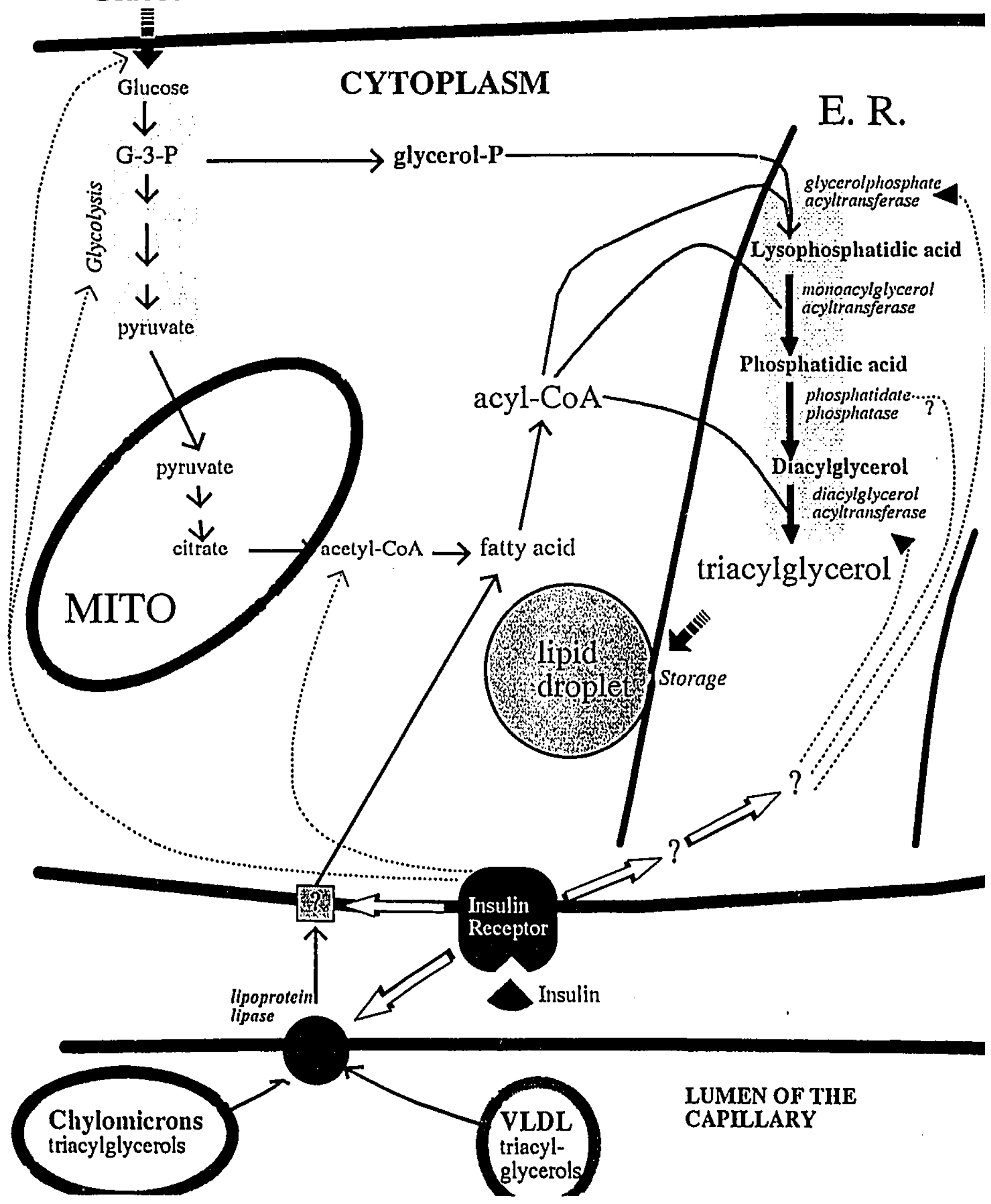




\section{3}

in the liver (115). Another study which investigated the effects of okadaic acid demonstrates that a complex cascade exists which involves PSPase activities in addition and independent of the PTPase activities (116). In the context of TAG synthesis and its regulation by insulin, Figure 17 shows a model for the multiple effects of insulin on glucose transport, glycolysis, fatty acid synthesis, lipoprotein lipase secretion and modulation of TAG synthetic enzyme activities. The mechanism of action of insulin is unclear but is believed to involve a cascade of kinases and phosphatases initiated by the insulin receptor tyrosine kinase. Whether a phosphatase or kinase is next in the signalling cascade remains to be determined. The remaining distal intermediates (i.e., kinases/phosphatases and their respective target enzymes) involved in insulin action (e.g., insulin effects of TAG synthesis) have yet to be elucidated. Furthermore the mechanism of regulation of adipocyte TAG synthesis by other hormones including growth hormone and leptin, likely involves a signalling pathway comprised of kinases and/or phosphatases acting on various target enzymes via a phosphorylationdephosphorylation mechanism.

Only one other soluble protein tyrosine kinase has been purified from $3 \mathrm{~T}_{3}$ cells. Its molecular weight was reported to be $53 \mathrm{kDa}$ and has been suggested to be involved in insulin-independent regulation of glucose metabolism $(102,103)$. Whether this kinase or our tyrosine kinase are involved in a phosphorylation cascade leading to DGAT inactivation remains to be established. 
64

From a different perspective, as suggested by Sohling et al., [84]it is possible physiologically that DGAT, in certain tissues, may be regulated by a phosphorylation mechanism, and thereby play a role in the nuclear inositol signalling cascade through DGAT's effects on the accumulation of DAGs. 


\section{5 \\ CONCLUDING REMARKS .}

Compared to nucleic acids and proteins, little attention has been given to the regulation of compartmentalization, packaging, transport, differential synthesis, intracellular movement of lipids both in the cell and in the body. This may be due to the relative difficulty in studying unstable membrane bound enzymes and the lipids which interact with them. However, some form of control over lipid metabolism must occur for a eukaryotic cell to have a compartmentalized nucleus, effective and viable plasma membranes and other organelles. Control must also occur for an organism to transport lipids to its component cells and meet their energy demands. The regulation of DGAT by a phosphorylation-dephosphorylation mechanism opens new avenues in the study of TAG, PL and lipoprotein synthesis as we!l as, of yet unidentified signal transduction pathways. 


\section{6}

Possible future directions. Further studies described below should provide greater insight into the physiological relevance and the identification of substrates of the purified protein tyrosine kinase.

1) Induction in adipocytes. DGAT and other lipogenic enzymes are induced in the process of adipocyte differentiation. It would be of interest to ascertain if the soluble tyrosine kinase is present in preadipocytes.

2) Identification/Purification of DGAT and GPAT enzymes could be attempted by incubating washed microsomes with the purified kinase and ${ }^{32} P$-ATP. running on PAGE under non-denaturing conditions, electro-eluting the bands correponding to phosphorylation substrates of the purified kinase and search for DGAT or GPAT activities. Alternatively antiphosphotyrosine antibodies could be instrumental for the selective precipitation of solubiiized phospho-DGAT and phospho-GPAT and, in that way, identifying the polypeptide bands corresponding to these acyltransferases. Once the subtrates have been identified, tyrosine phosphorylation could be demonstrated by performing phosphoamirioacid analysis of microsomal phosphoproteins. 


\section{7}

3) Purification of larger quantities of the purified kinase could allow the production of antibodies which could be used to screen libraries, in an attempt to clone the gene, or examine the presence of the kinase in different tissues and its role in the regulation of different enzymes including DGAT, GPAT, and ACAT, from various tissues.

4) Strong evidence for the physiological relevance of the phosphorylation/desphosphorylation of the synthetic enzymes could be obtained from studies of the hormonal effects on the kinase/phosphatase system. Adipocytes in primary cultures could be exposed to different hormones and endogenousiy formed ${ }^{32}$ P-ATP. The homogenates could be fractionated to purify the kinase and the corresponding PTK activity (with the synthetic peptide), and its labelling could be studied on SDS-PAGE. Furthermore once DGAT and GPAT have been identified from adipose tissue their phosphorylation could be studied by examining the effect of hormone treatment on endogenous microsomal phosphoprotein labelling.

5) Purification and identification of the adipose protein tyrosine phosphatases which function antagonistically with the tyrosine kinase could be important in proving that regulation of the acyltransferases occurs. Since we have detected an activity that could be associated with the phosphatase during the first few steps of 
68

the purification of the kinase, this would suggest a starting point for the fractionation of the adipose cytosol and the subsequent purification of the protein phosphatase. 


\section{9 \\ REFERENCES}

1) Spector AA (1986) In Biochemistry and Biology of Plasma Lipoproteins, ed. A. Scanu, A.A. Spector New York, Marcel Dekker press, p 247

2) Saggerson, E.D. (1988) in Phosphatidate Phosphohydrolase (Brindley, D.N., ed) Vol. 1, pp 80-124, CRC Press Inc., Boca Raton, FL

3) Fredrickson, D.S., Goldstein, J.L., and Brown, M.S. (1978) in the Metabolic: Basis of Inherited Diseases. Stanbury, J.G, Wyngaarden, J.B., and Fredrickson, D.S., eds.Ath Lid., McGraw Hill Book Co., Inc., New York, 604-655.

4) Minor, L.K., Rothblat, G.H., and Glick, J.M. (1989) 'Triglyceride and cholesteryl ester hydrolysis in cell culture model of smooth muscle foam cells. J. Lipid Res, 30,189-197.

5) Williams, M.L., Monger, D.J., Rutherford, S.L., Hincenbergs, M., Relifeld, S.J., and Grunfeld, C. (1988) J. Inher. Metab. Dis, 11,131-143.

6) Ebeling, P. and Koivisto, V.A. (1994). Non-esterified fatty acids regulate lipid and glucose oxidation and glycogen sy'nthesis in healthy men. Diabetologial 37(2),202-9.

7) Coppack, S.W., Jensen, M.D., and Miles, J.M. (1994) In vivo regulation of lipolysis in humans. J. Lipid Res. 35,177-193.

8) Rash, J.M., Rothblat, G.H., Sparks, C.E. (1981). Lipoprotein and apolipoproteins synthesis by human hepatoma cells in culture. Biochim. Biophys. Aclal 666,294-298

9) Ellsworth, J.L., Erickson, S.K., and Cooper, A.D. (1986). Very low and low densily lipoprotein synthesis and secretion by the human hepatoma cell line HepG2: effects of free fatty acid. J.Lipid Res, 27,858-874

10) Dashti, N., and Wolfbauer, G. (1987). Secretion of lipids, apolipoprotcins and lipoproteins by human hepatoma cell line HepG2:effects of oleic acid and insulin. LLipid Res. 28,423

11) Arner, P., Engfeldt, P., and Ostman, J. (1982) Changes in the metabolism of fatly acids in adipose tissue in obese patients with primary hypertriacylglycerolemia J. Lipid Res, 23,422-427 
12) Larsson, B.O., Bjorntorp, P., Holm, J., Schersten, T., Sjostroin, L., and Smith, U. (1975) Adipocyte metabolism in endogenous hypertriglycerolemia. Medibolism, 24,13751389

13) Rubba, P. (1978) Fractional fatty acid incorporation into human adipose (FAT), Hypertriglyceridemia. Athersclerosis 29,39-42

14) Carlson, L.A., Walldius, G., (1976). Fatty acid incorporation in adiposse tissue in hypertriglyceridemia. Eur. J. Clin. Invest 6,195-211.

15) Teng, B., Thompson, G.R., Sniderman, A.D., Fortc, T.M., and Krauss, R.M., and Kwiterovich, P.O. (1983) Composition and distribution of L.DI. fractions in hyperapobetalipoproteinemia, normolipidemial, and familiar hypercholesterolemiat. Proc. Natl. Acad. Sci. U.S.A. 80,6662-6666.

16) Genest, J., Sniderman, A.D., Cianflone, K., Teng, B., Wacholder, S., Marcel, Y., Kwiterovich, P.O., (1986). Hyperapobetalipoproteinemia, plasma lipoprotein responses 10 an oral fatty acid load. Arteriosclerosis 6,297-304.

17) Teng, B., Forse, A., Rodriguez, A., Sniderman, A.D. (1988) Adipose tissue glyceride synthesis in patients with hyperbetalipoproteinemia. Can, J, Physiol, Phallmacol, 66,239. 242.

18) Cianflone, K., Rodriguez, M.A., Walsh, M., Vu, H., and Snidermau, A.D. (1988). The effect of a plasma protein fraction on lipid synthesis in cultured skin fibroblasts from normals and patients with hyperapobetalipoproteinemia. Clin, Invest. Med, 11,99-107.

19) Ide, T., and Ontko, J.A. (1981). Increased secretion of very low density lipoprotein triglyceride following inhibition of long chain fatty acid oxidation in isolatce at liver. $L$ Biol. Chem, 256,10247

20) Saggerson, E.D. (1980) Regulation of lipid metabolism in adipose lissue and liver cells, in Biochemistry of cellular regulation, Vol.2, Ashwell, M., Ed. , CRC Press, Boca Raton, Fla., 207.

21) Harper, R.D., and Saggerson, E.D. (1976). Factors affecting fally acid oxidation in fat cells isolated from rat white adipose tissue.J.Lipid Res, 17,516.

22) Burns, T.W., Terry, B.E., Langley, P.E., and Robison, G.A. (1980). Role of cyclic AMP in human adipose tissue lipolysis. Adv, Cyclic Nucleotide Res, 12,329 
23) Fain, J.N. (1980). in the Hormonal regulation of lipid mobilization from adipose tissuc, in Biochemical Action of Hormones. Vol. 7, Litwack, G. Ed., Academic Press, New York, 119.

24) Belfage, P. (1985) in the Hormonal control of lipid degradation, in New Perspectives in A dipose Tissue: Structure, Function and Development, Cryer, A. and Van, R.L.R., Eds., Buttersworth, London, 121.

25) Iluttunen, J.K., Steinberg, D., and Mayer, S.E. (1970). ATP-dependent and cyclic AMP-dependent activation of rat adipose tissue lipase by protein kinase from rat skeletal muscle. Proc. Natl. Aciel, Sci, U.S.A., 67,290

26) Corbin, J.D., Reinmann, E.M., Walsh, D.A., and Krebs, E.G. (1970). Activation of adlipose tissuc lipass by skeletal muscle cyclic adenosine $3^{\prime}, 5^{\prime}$-monophosphate-stimulated protein kinasc. J. Biol. Chem. 245,4849.

27) Khoo, J.C., and Steinberg, D. (1974). Reversible protein kinase activation of hormone sensitive lipase in extracts of adipose tissue. L. Lipicl. Res. 15, 602.

28) Khoo, J.C., Steinberg, D., Huang, J.J., and Vagelos, P.R. (1976) Triglyceride, diglyceride, monoglyceride, and cholesterol ester hydrolase in chicken adipose tissue activated by adenosine 3',5'-monophosphate-dependent protein kinase. J. Biol. Chem, 251, 2882

29) Kloo, J.C., Steinberg, D., and Lee, E.Y.C. (1978) Activation of chicken adipose tissue diglyceride lipase by cyclic $A M P$-dependent protein kinase and its degradation by purified protein phosphatase. Biochem. Biophys. Res. Commun. 80, 418.

30) Stralfors, P., and Belfragc, P. (1983) Phosphorylation of hormone sensitive lipase by cyclic AMP-dependent protein kinase. J, Biol. Chem, 258, 15146.

31) Stralfors, P., Bjorgell, P., and Belfrage, P. (1984) Hormonal regulation of hormonesensitive lipase in intact adipocytes: identification of phosphorylated sites and effects on the phosphorylation by lipolytic hormones and insulin. Proc. Natl. Acald. Sci. U.S.A. 81, 3317.

32) Londos, C., Cooper, D.M.F., and Rodbell, M. (1981) Receptor-mediated stimulation and inhibition of adenylate cyclases: the fat cell as a model system. Adv. Cyclic Nucleotide Res., 14, 163. 


\section{2}

33) Birnbaumer, L., Codina, J., Mattera, R., Cerione, R.A., Hildebrandt, J.D., Sunyer, '1., Rojas, FJ., Caron, M.G., Lefkowitz, R.J., and lyangar, R. (1985). Regulation of hormone receptors and adenyly! cyclases by nucleotide binding $N$ proteins. Recenl Progr, Horm. Res, 41, 41,

34) Manganiello, V.V., Murad, F., and Vaughan, M. (1971). Effects of lipolytic and antilipolytic agents on 3',5'-adenosine monophosphate in fat cells. J. Biol. Chem, 246, 2195.

35) Londos, C., Honnor, R.C., and Dhillon, G.S. (1985) cAMP-dependent protein kinase and lipolysis in rat adipocytes. III. Multiple modes of insulin regulation of lipolysis ind regulation of insulin responses by adenylate cyclase regulators. J, Biol.Chem, 260, 15139.

36) Mayorek, N., Grinstein, I., and Bar-Tana, J. (1989) Triacylglycerol synthesis in cultured rat hepatocytes. The rate limiting role of diacylglycerol acyltransferase. Eulles Biochem. 702, 395-400

37) Stals, K., Mannaerts, G.P., and Decler(y, P.E. (1992) Factors influencing triacylglycerol synthesis in permeabilized rat hepatocytes. Biochem. J. 283, 719-725

38) Saggerson, E.D. (1972) The regulation of glycericle synthesis in isolated white-fatt cells. The effects of palmitate and lipolytic agents. Biocinem, J 128, 1057.

39) Saggerson, E.D., and Greenbaum, A.L. (1970). The regulation of triglyceride synthesis and fatty acid synthesis in rat epididymal adipose tissuc. Effects of insulin, adrenaline, and some metabolites in vitro. Biochem. J 119, 193.

40) Smith, S.J., and Saggerson, E.D. (1979) Regulation of pyruvate dehydrogenase activity in rat epididymal fat pads and isolated adipocytes by adrenaline. Biochem. J. $174,119$.

41) Newsholme, E.A., Arch, J.R.S., Brooks, B., and Surholt, B. (1983). The role of substrate cycles in metabolic regulation. Binchem. Soc. Trans. 11, 52.

42) Angel, A., Desai, K.S., and Halperin, M.L. (1971). Intracellular accumulation of frec fatty acids in isolated white adipose cells. J.Lipid Res. 12, 104-111.

43) Vaughan, M., Steinberg, D., and Pittman, R. (1964) On the interpretation of studics measuring uptake and esterification of [1-14C]palmitic acid by rat adipocytes in vitro. Biochim. Biophys. Acta 84, 154-166. 


\section{3}

44) Abumrad, N.A., Harmon, C.M., Barnele, U.S., and Whitesell, R.R. (1988). Insulin antagonism of catecholamine stimuiation of fatty acid transport in the adipocyte. J. Biol. Chem. 263, 14678-83.

45) Rodbell, M. (1965). Modulation of lipolysis in adipose tissue by fatty acid concentration in fat cell. Ann. N,Y,Acad, Sci, 131, 302-314.

46) Durocher, V., Miller, M., Rodriguez, M.A. (1990). Microsomal glycerolphosphate acyltransferase inactivation by fatty acids. Can.J. Physiol. Pharmacol, 68, 1255-1260.

47) Melki, S.A., and Abumrad, N.A. (1992) Glycerolipid synthesis in isolated adipocytes: substrate dependence and influence of norepinephrine. J.Lipid Res. 33, 669-678

48) Potter, B.J., Sorrentino, D. and Berk, P.D. (1989). Mechanisms of cellular uptake of free fatty acids. Annu. Rev, Nulr, 9, 253-270.

49) Glatz, J.F.C., and Vecrkamı, J.H. (1985). Intraceilular fatty acid binding proteins. Int.J. Biechem, 17, 13-22

50) Mishkin, S., and Turcolte, R. (1974). The binding of long chain fatty acid-CoA-Z, a cytoplasmic protein present in liver and other tissues of the rat. Biochem. Biophys. Res. Commun 57, 918.

51) O'Doherty, P.J.A., and Kuksis, A. (1975). Stimulation of TAG synthesis by Z-protein in rat liver and intestinal mucosi. FEBS Lett. 60, 256-8.

52) Burnett, D.A., Lysenko, N., Manning, J.A., and Ockner, R.K. (1979). Utilization of long chain fatty acids by rat liver: studies of the role of fatty acid binding proteins. Gisterocuterol, 77, 241-249.

53) Manley, E.R., Skrdlant, H.B., Hansbury, E., and Scallem, T.J. (1974). Conversion of diglyceride to triglyceride by rat liver microsomes: requirement for the $105000 \mathrm{xg}$ supernatant. Biochem. Biophys. Res. Commun, 58, 229-235.

54) Suzue, G., and Marcel, Y.L. (1975). Studies on the fatty acid binding proteins in cytosol of rat liver. Call, J. Biochem, 53, 804-809.

55) Roncari, D.A.K., and Mack, E.Y.W. (1981). Purification of liver cytosolic proteins that stimulate triacylglycerol synthesis. Can.J. Biochem, 59, 944-950

56) Greenwood, M.R.C., and Johnson, R.R. (1983) In the Adipose Tissue, in Histology, Cell and Tissue Biology, Weiss, L., Ed. Eisevier, Amsterdam, 178 


\section{4}

57) Novikoff, A.A., Novikoff, P.M., Rosen, O.M., and Rubin, C.S. (1980). Organelle relationships in cultured 3T3 L1 preadipocytes. J.Cell. Biol. 87, 180-196.

58) Slavin, B.G. (1979). Fine studies on white adipocyte differentiation Alll, Rec, 195, 63072.

59) Blanchette-Mackic, E.J., and Scow, R.O. (1984). Inl. J. Qbesity, 8, 67-73.

60) Franke, W.W., Hergt, M., and Grund, C. (1987). Rearrangement of the vimentin cytoskeleton during adipose conversion: Formation of an intermediate filanent case around lipid globules. Cell, 49, 131-141.

61) Tijburg, L.B.M., Geelen, M.J.H., and VanGolde, L.M.G. (1989) Regulation of the biosynthesis of TAG, PC, and PE in the liver. Biochim, Biophys. Actia 1004, 1-19

62) Pedersen, S.B., Borglum, J., Jorgensen, J.O.L., Richelsen, B. (1994) Growilı hormone administration to obese premenopalusal women-effects on isolated adipose metabolism. Inter. J, Obesity 18(2), 356.

63) Heathers, G.P., Al-Muhtaseh, N., and Brunt, R.V. (1985) The effect of adrenergic agents on the activity of glycerol 3-phosphate acyleransferase and triglyceride lipase in the isolated perfused rat heart. J. Mol. Cell Cardiol, 17, 785-796

64) Soorana, S.R., and Saggerson E.D. (1978) Studies of the effects of adrenaline on glycerol phosphate acyltransferase activitics in rat adipocytes. FEBS Letl. 90, 141-144

65) Vila, M.C., and Farese, R.V. (1991) Insulin rapidly increases glycerol-3-phosphite acyltransferase activity in rat adipocytes. Arch. Biochem, Biophys, 284, 366-368

66) Rider, M.H., and Saggerson, E.D. (1983) Regulation by noradremaline of mitochondrial and microsomal forms of glycerol phosphate acyltransferase in rat adipocytes. Biochem. J, 214, 235-246.

67) Bell, R.M. and Coleman, R.A. (1980) Enzymes of glycerolipid synthesis in eukaryotes. Ann, Rev, Biochem, 49, 459-87.

68) Brindley, D.N. (1984) Intracellular translocation of phosphatidate phosphohydrolase and its possible role in the control of glycerolipid synthesis. Prog Lipid Res. 23, 115-133

69) Cheng, C.H.K, and Saggerson, E.D. (1980) The inactivation of rat adipocyte Mg2+ dependent phosphatidate phosphohydrolase by noradrenaline. Biochem J. 190, 659-662 


\section{5}

70) Cheng, C.H.K., and Saggerson, E.D. (1978) Rapid antagonistic actions of noreadrenaline and insulin on rat adipocyte phosphitidate phosphohydrolase activity. FEBS LCLIl., 93, 120.

71) Haagsman, H.P., de Haas, C.G.M., Geelen, M.J.H., and van Golde, L.M.G. (1981) Biochim. Biophys, Acha, 664, 74-81

72) Haagsman, H.P., de Haas, C.G.M., Geelen, M.G.H., and Van Golde, L.M.G. (1982) Regulation of triacylglycerol synthesis in the liver. J. Biol. Chem, 257, 10593-10596

73) Trotter, P.J., and Storch, J. (1993) Fatty acid esterification during differentiation of the human intestinal cell line Caco-2. J. Biol. Chem. 268, 10017-23.

74) Sauros, V.S., and Strickland, K.P. (1990) Triacylglycerol synthesis and diacylglycerol acyltransfcrase activity during skelctal myogenesis. Biochem. Cell Biol, 68, 1393-401.

75) Gimes, G., and Toth, M. (1993) Low concentration of triton x-100 inhibits diacylglycerol acyltransferase without measurable effect on phosphitidate phosphohydrolase in the human primordial placenta. Acan Physiologica Hungarica 81, $101-8$

76) Ide, 'T., Hirabayashi, S., Kano, S., and Suguno, M. (1992). Soybean phospholipid dependent reductions in triacylglycerol concentration and synthesis in the liver of fastrefed rats. Biochim. Biophys. Acta. 1124, 163-170.

77) Abumrad, N.A., Forest, C., Regen, D.M., Barnella, U.S., and Melki, S.A. (1991). Mctabolism of oleic acid in differentiating BFC-1 preadipose cells. Amer. J. Physiol, $261,76-86$.

78) Stals, H.K., Top, W., and Declerq, P.E. (1994) Regulation of triacylglycerol synthesis in permeabilized rat hepatocytes. Role of fatty acid concentration and diacylglycerol acyltransferase. FEBS Lett. 343, 99-102.

79) Ide, T., and Murata, M. (1993) The acyl-acceptor specificity of microsomal diacylglycerol acyltransferase as a possible determinant in regulating hepatic triacylglycerol synthesis in rats fed a polyunsaturated diet. J. of Nutr. Biochem, 4, 229235.

80) Perry, H.Y., and Harwood, J.L. (1993) Radiolabelling studies of acyl lipids in developing seeds of Brassica napus: Use of [1-14C] acetate precursor. Phytochemistry 33, 329-333. 


\section{6}

81) Schoonderwoerd, K.. Broekhoven-Schokker, S., Hulsmimn, W.('., and Stam. HI. (1990) Properties of phosphatidate phosphohydrolase and diacylglycerol acyltransferasse activities in isolated rall heart. Effect of glucigon, ischacmia and dialhetes. Biofihem! $268,487-492$.

82) Nimmo, H.G., and Houston, B. (1978) Rat adlipose tissue glycerol phospluatle

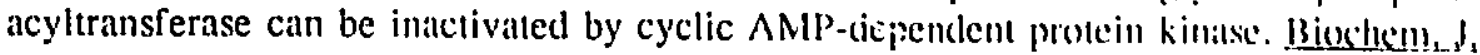
$176,607-610$

83) Berglund, L., Bjorhem, I., and Einarsson, K. (1982) Apparent phosphloryliationdephosphorylation of soluble phosphaticlic acid phosphatase in ral liver. Bischentil. Biophys. Res. Commun. 105, 288-295

84) Soling, H.D., Fest, W., Schimdt, T., Esselman, H., and Bachmamn. V. (1989) Signil transmission in exocrine cells is associated with rapid activity changes of alcyllamslerases and diacylglycerol kinase due to reversible protein phosphorylation. 1._Biol. (1hent, 264, 10643-10648

85) Butterwith, S.C., Martin, A., and Brindley, D.N. (1984) ('an plusplunylition of phosphatidate phosphohydrolase by a cyclic $\Lambda \mathrm{MP}$-dependeme meclamism regulate its activity and subcellular distribution and control hepatic glycerolipid sy'mesis. Bioclicun J. $222,487-493$

86) Nimmo, G.A., and Nimmo, II.G. (1984) Studies of ral adipose tissue microsomial glycerol phosphate acylannsferase. Biochem. J 224, 101-108

87) Walsh, M., Durocher, V., and Rodriguez., А. (1989). Reversihle A'T'-depenctent inactivation of glycerol phosphate acyltransferase from rat adipose tissue. Biocleem. (ell. Biol.67,48-52

88) Hare, J.F., Taylor, K. and Holocher, ^. (1993) Fnergy dependent proteintriacylglycerol interaction in a cell free system from 3'T3-L, I adipocyles. I, Biol. Cheill. $269,771-6$.

89) Rodriguez, M.A., Dias, C., and Lilu, T. (1992) Reversible $\Lambda$ TP-dependenl inactivation of adipose diacylglycerol acyltransferase. Lipicks, 27,577-58 I

90) Bishop, J.E., and Hajra, A.K. (1980) A method for the chemicall symbesis of IA('labeled fatty acyl Coenzyme $A$ 's of high specific activity. Anal, Bioc(lem. 106,344-3.50) 
91) Rodriguez, A., Riendeau, D., and Meighen, E. (1983) Purification of the acyl coenryme $A$ reductase component from a complex responsible for the reduction of fatty acids in bioluminescent bacteria. J. Biol. Chem, 258, 5233-5237

92) Jarret, L. (1979) in Mcth. Enzymol, Subcellular fractionation of adipocytes 31 A, 6071

93) Durocher, V., Miller, M., and Rodriguez, M.A. (1990) Can_J. Physiol. Pharmacol. $68,1255-1260$

94) Brandt, H., Capulong, Z.L., and Lee, E.Y.C. (1975) Purification and properties of rabbit liver phosphorylase phosphatase. J. Biol. Chem. 250,8038-8044

95) Rodriguez, M.A., Dias, C., and Lalu, T.E. (to be submitted 1994) Delivery of acylCoA to microsomal acyltransferases. Can. J. Pliysiol. Pharn acol.

96) Pike, L.J., Eakes, A.T., and Krebs, E.G. (1986) Characterization of affinity-purified insulin receptor/kinase. J. Biol. Chem, 261, 3782-3789.

97) Bradford, M.M. (1976) $\wedge$ rapid and sensitive method for the quantitation of microgram quantitics of protein utilizing the principle of protein-dye binding. Anal. Biochem, 72, 248-254

98) Lacmmli, U.K. (1970) Cleavage of structural proteins during the assemble of the head bacteriophage T4. Nature 227, 680-685

99) Enright, W.J., and Booth, P. (1992) Specificity of inhibitors of tyrosine kinases. Eocus 13(8), 79-82

100) Hu, Y., and Conway, T.W. (1993), 2-aminopurine inhibits the double stranded RNA-dependent protein kinase both in vitro and in vivo. J. Interferon Res, 13, 323-328

101) Shisheva, A., and Y. Shechter. (1992) A cytosolic protein tyrosine kinase in rat adipocytes. EEBS Lett. 330, 93-96.

102) Shisheva, A., and Shechter, Y. (1993) Role of cytosolic tyrosine kinase in mediating insulin-like actions of vanadate in rat adipocytes. J. Biol. Chem. 268, 64636469.

103) M.A. Rodriguez, Lau, T.E., and J. Lapperriere. (1994) Inhibition of adipose and hepatic acyltransferases. Can. J. Physiol. Pharmacol.72(1), 444 


\section{8}

104) Nimmo, H.G. (1980) in the Mol. Aspects Cell Regul.l. Recently discovered systems of enzyme regulation by reversible phosphorylation Cohen, P. ed. lilsevier publishing, 135-152.

105) Severson, D.L., and Sloatn. S.K. (1977) Inhibition of the reversilnte deaterivaltion of chicken adipose tissue hormone sensitive lipase by heat stahle proteins fom andipose tissue and skeletal muscle. Biochem. Biophys. Res. Commun. 79, 1(1.45-10150).

106) Secrist, J.P., Burns. L.A.. Karnitz, L.., Koretzky, G.A., and NMillaim, R.I. (1(4)3)

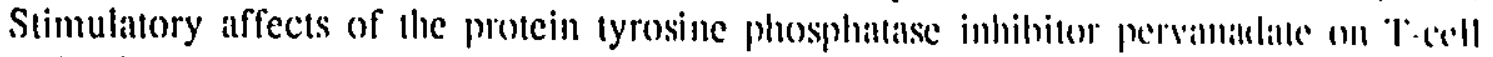
activation events. J. Biol. Chem. 268, 5880

107) Cohen, P., Holmes, C.F.B., and Tsukitani, Y. (1990) Okatdaic ancid: a new probe for the study of cellular regulation. TIBSS $15,98$.

108) Kwanyuen, P., and Wilson, R.F. (1990) Subunit and amino acid composition of

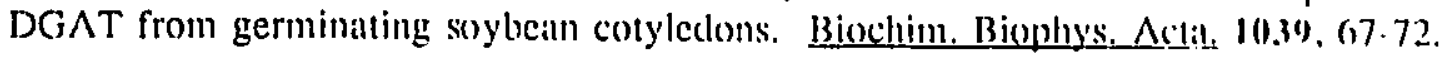

109) Ozasa, S., Kempner, E.S., and Erickson, S.K. (1989) fiunclionil size of acyl coenzyme A:diacylglycerol acyltransferatse by racliation intativation. 1. 1.jpid Res. 30. $1759-62$

110) Green, P.R., Merrill, A.H.Jr., and Bell, R.M. (1981) Membranc phosphoblipicl synthesis in Escharichia coli. J. Biol. Chem, 256, 11151-11159)

111) Yet, S.F., Lee, S., Young, T.II., and Sul, H.S. (1993) Expression and ielentification

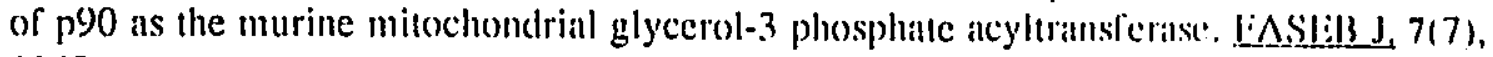
1248

112) Rothenberg, P.L., Jane, W.S., Karasik, A., Balcker, J., White, M., andl Kallul, ('.R.

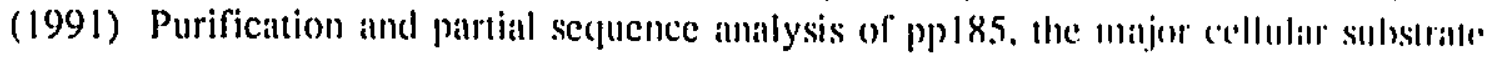
of the insulin receptor kinase. J. Biol. Chem. $266,8302-11$.

113) Greenberg, A.S., Egan, J.J., Wek, S.A., Garty, N.B., Blanclicule-Malckic, İ.J., inncl Londos, C. (1991). Perilipin, a major homonally regulated indipocyte-specific phosphoprotein associated with the periphery of lipid storige droplets. J. Biol. Sheme $266,11341-11346$.

114) Kenner, K.A., Hill, D.E., Olefsky, J.M., and Kusari, J. (1993) Regulation of protein tyrosine phosphatases by insulin and insulin-like growth factor. L $\mid$ Siol, Chem, 268, 25455-62. 


\section{9}

115) Begum, N., Sussman, K.E., and Draznin, B. (1991) Differential effects of diabetes on adipocyte and liver phosphotyrosine and phosphoserine phosphatases activities. Diabetes, 40 (12), 1620-1629.

116) Shisheva, A., and Shechter, Y. (1991) Effect of okadaic acid in rat adipocytes: differential stimulation of glucose and lipid metabolism and induction of refractoriness to insulin and vanadate. Endocrinology 129 (5), 2279-2288. 


\section{Appendix A}

\section{List of Abbreviations}

The abbreviations used are listed in alphabetical order: ATP, adenosine 5'triphosphate; BSA, bovine serum albumin; cAMP, cyclic adenosine monophosphate; CoA, coenzyme A; DAG, diacylglycerol; DGAT, diacylglycerol acyltransferasc; D'TT, DL-dithiothreitol; EDTA, ethylenediaminetetrancetate, FA, falty acid; FABP, fally acid binding protein; GPA't, glycerolphosphate acyltransfernse; IIPLC, high perfornance liquid chromatography; ISL, homone sensitive lipase; IR, insulin, receptor; LPA, lysoplosphatidic acid; MGAT, monoacylglycerol acyltransferasc; PAGE, polyacrylamide gel electrophoresis; PAP, phosphatidic acid phosphatasc; PLG, polyethylene glycol compound; PL, phospholipid; PKA, protein kinase $\Lambda$; PKC, protein kinase C; PPase, protein phosphatase; PTK, protein tyrosine kinnse; IPSP, prolein serine phosphatase; PTP, protein tyrosine phosphatase; TAG, triacylglycerol. 


\section{Appendix B CURRICULUM VITAE}

'Timothy E. Lau

Academic Address:

Department of Biochemistry

Faculty of Medicine

140 Louis Pasteur

Ottawa, Ont.,

K1N 6N5

(613) 564-3467
Home Address:

42 Whippoorwill Dr.,

Gloucester, Ont.,

K1J 7 H9

(613) $745-8084$

\section{EDUCATION}

1993-

1992-1994

1988-1992

\section{ACADEMIC AWARDS}

1992-1993

\section{PROFESSIONAL EXPERIENCE}

1992-present

1993

1992

1991-1992

1991
Doctorate of Medicine (M.D.)

University of Ottawa

Masters in Biochemistry (M.Sc.) (submitted) University of Ottawa

Bachelor of Science (BSc.(Hon.) University of Ottawa

At Excellence Scholarship

Masters research

-Teaching assistant/

Demonstrator

Summer research project

Fourth year research projects

Summer research project

\section{PUBLICATIONS}

1) Rodriguez, M.A., Dins, C., and Lau, T.E. (1992) Reversible ATP-dependent inactivation of adipose diacylglycerol acyltransferase. Lipids 27,577-581 
2) Rodriguez, M.A., Lau, T.E., and Dias, C. (1992) in Drugs Affecting Lipid Metabolism. Regulation of triglyceride synthesis by a kinase-phosphatase system. Catapano, A.L., Gotto Jr., A.M., Smith, L.C., and Paoletti, R. Fids. Klumer academic publishers. Dordrecht, Netherlands, 149

3) Lau, T.E., and Rodriguez, M.A. (1993) Diacylglycerolacyltransferase kimase. FASEB J, 7(7),639

4) Rodriguez, M.A., Lan, T.E., and Dias, C. (1993) Effects of Antipsycholic Drugs on Lipid Synthesis. CFBS Proceedings.

5) Rodriguez, M.A., Dias, C., and Lau, T.E. (1994) Acyl-CoA delivery to microsomal acyltransferases. CFBS Proceedings, l'S56.

6) Rodriguez, M.A., and Lau, T.E. (1994) ^ protein tyrosine kinase assuciated with the ATP-dependent inactivation of diacylglycerol acyltransferase. Int. J. Qbesity 18(2),245

7) Rodriguez, M.A., Lau, T.E., and Lapperiere, J. (1994) Inlibition of adipose and hepatic acyltransferases by antipsychotic drugs. Can. J. Physiol, Pharmacol. $72(1), 444$

\section{PAPERS TO BE SUBMITTED}

1) Rodriguez, M.A., Dias, C., and Lau, T.E. (1994) Acyl-CoA delivery to microsomal acyltransferases. Paper to be submitted to Can. J. Phys. Pharm.

2) Rodriguez, M.A., Lapperiere, J., and Lau, T.E. (1994) Inhibilion of adipose and hepatic acyltransferases by antipsychotic drugs. Paper to be submilted to Biochemical Pharmacology.

3) Lau, T.E., and Rodriguez, M.A. (1994) ^ prolein tyrosine kinase associaled with the ATP-dependent inactivation of diacylglycerol acyltransferase. Paner to be submitted to Lipids.

\section{ACADEMIC STUDEN'I SERVICE}

1993

1993

$1992-93$

$1992-93$

1992

1992

1991-92

1990-91

1989-90
Vice President, Student affairs

Graduate Students Federation (GSAED)

Student representative to the University Commiltec for Campus security

Graduate student represcntative to the departmenlal curriculum cominitlee

President/ Biochemistry graduate students association

Biochemistry delegate for the GSAED council

Student representative of the University Strategic

Planning Committec. Support staff analysis (UIP')

President and Founder of the Undergraduate Biocliemisiry

Students Association (SFUO).

Vice-President Social. Science Students Association (SSA)

Bioclemistry representative to the SSA 